A Carbon Sequestration Supply Function And

Development of Feasible Clean Development Mechanism

Rules for Tropical Forest Carbon Sinks

by

Suzi Kerr, Motu Economic Research, New Zealand

Alexander S.P. Pfaff, Columbia University

Et al.

June 1999

Discussion Paper Series No. 9899-08

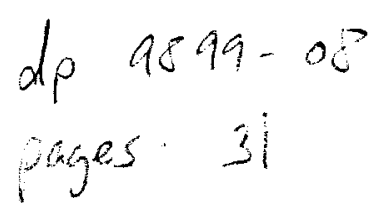




\title{
a Carbon Sequestration Supply Function And Development Of Feasible Clean Development Mechanism Rules FOR TROPICAL FOREST CARBON SINKS
}

\author{
a work plan for multi-disciplinary estimation and integrated sensitivity analysis \\ making use of Costa Rica as a data-intensive case study *
}

Suzi Kerr, Alexander S.P. Pfaff, R. Flint Hughes, Shuguang Liu, G. Arturo Sanchez-Azofeifa, David Schimel, Joseph Tosi and Vicente Watson **

\footnotetext{
* This working paper has grown out of ongoing research on carbon sequestration and land use in Costa Rica. The authors thank for generous support the Tinker Foundation's Institutional Grant in support of the project "Achieving Greatest Benefits from Sequestration in Costa Rica", the Center for Environmental Research and Conservation at Columbia University, the Harvard Institute for International Development, and the National Center for Ecological Analysis and Synthesis at UC-Santa Barbara, a Center funded by NSF (Grant \#DEB-94-21535), UC-Santa Barbara, and the State of California, where we have been supported as the Carbon Sequestration Working Group.

** Suzi Kerr is at Motu Economic Research, Wellington, New Zealand (suzi.kerr@clear.net.nz). Alex Pfaff is at Columbia University, School of International and Public Affairs, Department of Economics, and Center for Environmental Research and Conservation (ap196@columbia.edu). Flint Hughes is at the University of Colorado (hughesf@terra.colorado.edu), Shuguang Liu is at the U.S.G.S./EROS Data Center (sliu@edcmail.cr.usgs.gov), Arturo Sanchez is at the University of Alberta, Canada (arturo.sanchez@ualberta.ca), Joseph Tosi and Vicente Watson are at the Tropical Science Center, San Jose, Costa Rica (jtosi@cct.or.cr \& vwatson@cct.or.cr).
} 


\begin{abstract}
With the rise in importance of global climate change, society is actively exploring the possibility of using forest ecosystems as a carbon sink. Tropical forests may offer over two-third of such opportunities. The protection of tropical forests could offset global fossil fuel $\mathrm{C}$ emissions and reduce the cost of emissions limitations set in Kyoto, and certified emissions credits (CERs) under the Clean Development Mechanism (CDM) established in Kyoto will likely incorporate tropical forest sinks within efforts to meet emissions targets. While this could in principle result in significant economic and sequestration benefits, actual evidence on tropical $\mathrm{C}$ sinks is sparse. However, society must soon make key decisions concerning tropical forest sinks in the CDM.
\end{abstract}

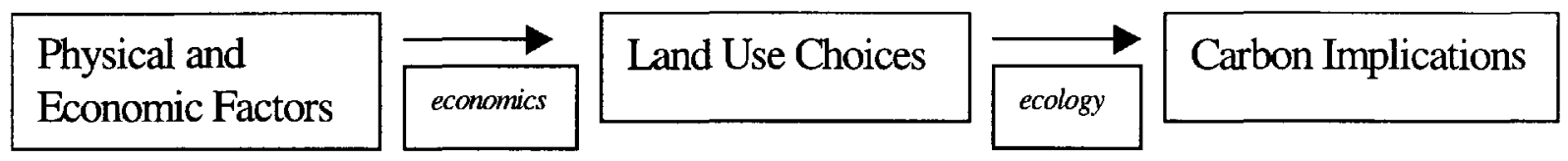

The first major goal of our project is to estimate how much $C$ sequestration will be generated in Costa $\mathrm{Rica}$ in response to any given monetary reward for $\mathrm{C}$ sequestration. Our advances in the ecological and economic components will be coupled to produce our first integrated output, an estimated supply or, equivalently, cost function for $\mathrm{C}$ sequestration (i.e., a relationship between the $\mathrm{C}$ reward and the $\mathrm{C}$ sequestration supplied by land users). Our estimated function will itself answer policy questions about the effects of $C$ payments, and will provide a basis for estimating the value that accrues globally and to individual countries from using $\mathrm{C}$ trading within the efforts to implement emissions limitations. It can also be plugged into integrated assessment models.

Our advances in the economic component start with excellent existing GIS databases on land use and land cover, and on the factors expected to affect land use choices. We will extend both of these types of data sets, in particular extending land-cover information back in time, and adding improved data on land returns. Next, we will both apply and extend the frontier of economic, observationally-based modeling of land use to provide a map from key factors to land choices.

On the ecological side, our advances start with systematic and comprehensive measurement of aboveground and soil $\mathrm{C}$ present within the range of forest ecosystems of Costa Rica, as well as the $\mathrm{C}$ dynamics within land-use gradients of each of those systems (e.g., pastures, croplands, and secondary forests of varying ages). With this and existing data, we will calibrate and verify both process-based and empirically-based ecological models that generate $\mathrm{C}$ predictions of varying complexity. This provides a map to $\mathrm{C}$ stocks from land use choices within different ecosystems.

Our second goal is to contribute to the effective design of the rules that allow $\mathrm{C}$ sequestration in tropical locations to replace emissions reductions in developed countries. Our analyses will provide the necessary information for the baselines that permit CERs to be defined, and a $\mathrm{C}$ market to function. We will also perform integrated sensitivity analyses to determine whether simplified versions of our disciplinary and integrated models maintain sufficient accuracy. Sufficient accuracy will ensure the sequestration outcomes envisioned, while greater simplicity, which translates to lower costs of participation in trading, will stimulate further participation, lowering costs and raising the efficiency of implementation of the Kyoto emissions limitations. 


\section{Introduction}

With the rise in importance of potential global climate change, decision makers are actively exploring the possibility of using forests as a carbon sink. The tropics may offer over two-thirds of such opportunities (see, e.g., Rodriguez et al. 1998 on Central America). In Kyoto, developed countries agreed to limit their emissions to 5\% (on average) below 1990 levels by the period 2008-2012. Meeting these commitments will require significant cost and changes in energy use. In response to this challenge, it has been suggested that initiatives to slow deforestation and to promote natural forest regeneration and forestation could offset 12-15\% of global fossil fuel carbon emissions from 1995 to 2050 (see the last IPCC assessment, Watson et al. 1996).

The creation of certified emissions credits (CERs), under the Clean Development Mechanism established in Kyoto, could incorporate tropical sequestration within the effort to meet the Kyoto targets. This could yield economic and sequestration benefits, from lower costs of implementing the agreed emissions limitations. To this point, though, integrated assessment (IA) of the value of incorporating tropical sequestration has been based on limited case studies using inadequate data, and analytical studies inadequately linked to data. In short, evidence on the potential of tropical carbon sinks is sparse. However, despite the lack of reliable information, soon the international community must make key decisions on whether and how to include tropical sinks in the Clean Development Mechanism. How valuable would carbon sequestration really be? Can we create a credible, workable system to reward additional efforts to sequester carbon?

In light of these questions, we propose an integrated approach to assessing carbon-sequestration policies. The foundation of this approach will be advances in both economic and ecological analysis, for Costa Rica, which will serve as an intensive case study. Thus, while our broader goals are to contribute to integrated assessment of climate change policies, our first objectives are state-of-the-art economic and ecological analyses for Costa Rica. On the economic side, we start with extensive and detailed GIS databases we have already developed on actual land use and land cover as well as the factors expected to affect land-use choices in Costa Rica. We will extend these data sets, in particular with land-cover information further back in time and improved data on the returns to land uses. We will then both apply and extend the state-of-the-art in economic, observation-based modeling of land use, yielding a map from key factors to land-use choices.

On the ecological side, we start with an extensive and intensive quantification of $\mathrm{C}$ pools and dynamics in forest ecosystems across Costa Rica. This will be accomplished through the systematic and comprehensive measurement of aboveground and soil $\mathrm{C}$ present within Costa Rican forests ranging from tropical wet to tropical dry life zones. In addition, we will quantify $\mathrm{C}$ pools along land-use gradients that exist within of each of the respective life zones. In this way, we will provide measures of $\mathrm{C}$ dynamics in response to land-use change throughout Costa Rica. Next, using this data, we will both calibrate and verify both process-based and empirically-based ecological models of varying complexity, each of which will yield predictions of $\mathrm{C}$ dynamics.

Our first integrated assessment goal is to estimate how much $\mathrm{C}$ sequestration will be generated within Costa Rica in response to any given monetary reward for $\mathrm{C}$ sequestration. Coupling our advanced disciplinary components yields our first integrated output, an estimated supply, or cost, 
function for $\mathrm{C}$ sequestration (i.e., a functional relationship between the monetary $\mathrm{C}$ reward and the $\mathrm{C}$ sequestration supplied by land users). Such a function, whose estimation for Costa Rica will be designed for relevance elsewhere as well, will provide a basis for estimating the value (both to a given country and globally) of using $\mathrm{C}$ trading within efforts to implement emissions limitations. This type of function can also be an input to existing integrated assessment models.

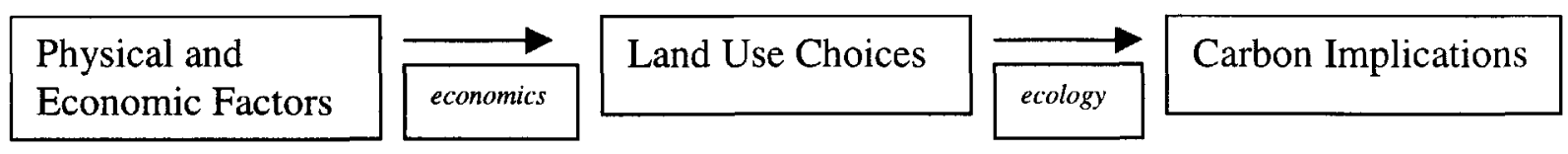

Our second integrated assessment goal is to contribute to the effective design of the rules that could allow $\mathrm{C}$ sequestration efforts in any number of tropical locations to replace emissionsreduction efforts in, for instance, developed northern countries. For a $\mathrm{C}$ market to function in this way, there need to exist credible international rules determining $C$ sequestration baselines (i.e., what would occur if no policy initiatives take place). Then society rewards countries only for the $\mathrm{C}$ sequestration over and above baseline, and emissions rise correspondingly in northern countries. Fortunately, our integrated analyses provide the information for such baselines. The basic economic research objective is to analyze outcomes in various (counterfactual) scenarios, while the basic ecological research objective is to provide functions for estimating $\mathrm{C}$ stocks, and their changes, that result from $\mathrm{C}$ sequestration efforts. These determine the number of CERs to award (as in Figure 1 below, where CERs for $\mathrm{C}$ sequestration are defined relative to a baseline).

Another research objective, given this second goal, arises because the rules that define CERs should be designed to enhance the economic efficiency of sequestration and the sequestration impacts of $\mathrm{C}$ trading. For both economic and ecological analyses, we will perform sensitivity analyses in order to determine whether versions of the models which are simpler and easier to produce and use than the state-of-the-art can maintain sufficient accuracy. Sufficient accuracy will help to guarantee that the sequestration outcomes envisioned will in fact come about. Ease of use of the models (i.e., the bases for the CER rules) will translate into lower costs for countries participating in $\mathrm{C}$ trading, and thus stimulate further participation. This in turn will raise the efficiency, by lowering the overall costs, of implementing the Kyoto emissions limitations.

Costs may be lowered by reducing the data demanded for estimation of the models for any given country. However, a simplified, lower-cost model will almost surely also possess less predictive power than the full model from which it is derived. Thus, there is a tradeoff within the choice of model, between the models' accuracy and their costs. As part of our team's early work (which has been supported by the Tinker Foundation and the National Center for Ecological Analysis and Synthesis), we have carefully considered this tradeoff, as well as its primary implication: the best rules for an actual CER system may not be the scientifically most accurate possible rules.

While these two IA goals are distinct, we take a single basic approach to each of the analyses required. For a $\mathrm{C}$-sequestration supply function, and for $\mathrm{C}$ baselines, we want to develop the models which best explain land use and $\mathrm{C}$ storage in Costa Rica. For effective design of the rules for $\mathrm{C}$ rewards, we want to find simplified versions of the models which retain much of the accuracy of the best models, but are easier and cheaper to use. In the pursuit of each of these 
goals, though, Costa Rica will serve as an intensive case study. Also, for each goal, i.e. for both the full and the simplified models, we will use the great availability of data for Costa Rica to generate estimates which are not only locally accurate but also as generalizable as possible. Greater generality of such estimates will make them of increased interest as inputs to IA models.

Figure 1: Definition of Certified Emission Reduction - CER

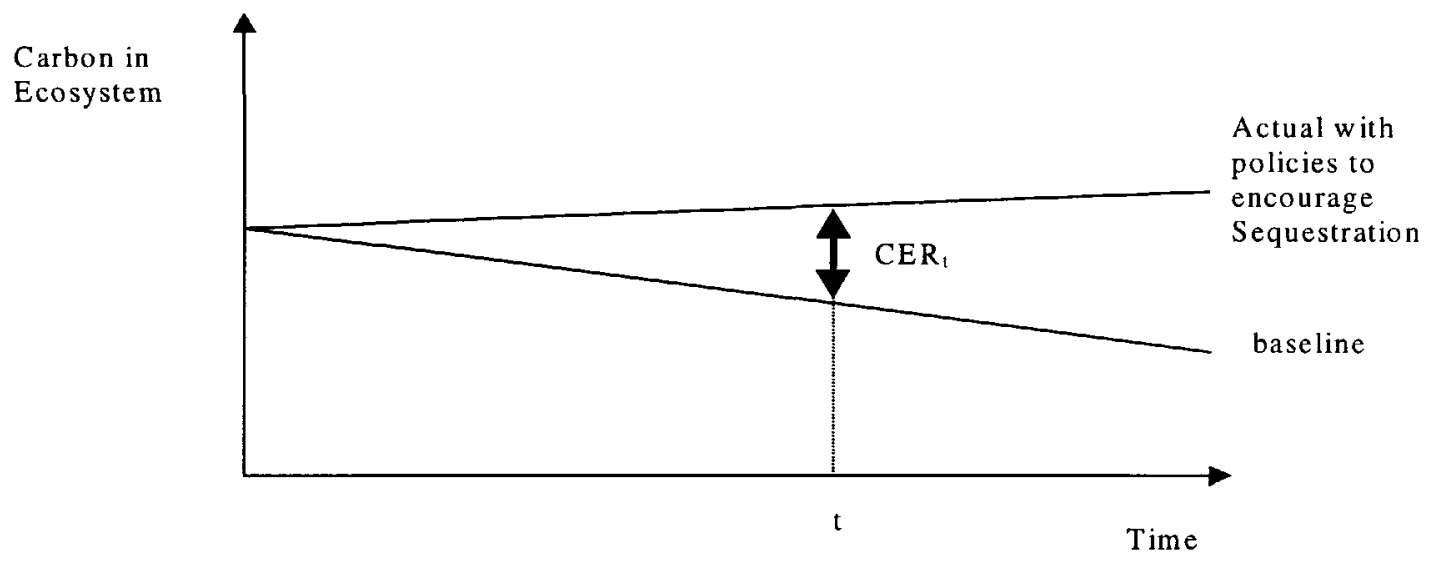

For all of our outputs, we will use both cutting-edge economic and ecological methodology and high-quality data sets. From our extensions of the spatially explicit GIS data sets we have previously developed, we will study land cover for all of Costa Rica over the period 1945-1997. From our major extensions of the existing field data sets we will have an extensive and detailed knowledge of $\mathrm{C}$ and $\mathrm{N}$ pools across the country. Generally, Costa Rica is an ideal case study given its data sets, variation in ecological conditions, small size and export orientation, and the various stages of economic development it experienced during the time period that we will study.

Thus, our project will generate a high-quality, integrated, spatially explicit model for Costa Rica with empirical results applicable to similar regions. It will facilitate future analysis and will demonstrate a new integrated methodology. Further, our sensitivity analysis of simpler rules is a search for a sufficiently accurate CER rule that is not too cumbersome for use in $\mathrm{C}$ markets. If such integrated analysis can not produce a workable and credible rule, society will not be able to reap the potential of tropical forest $\mathrm{C}$ sinks. This work is also a step towards a credible empirical basis for the tropical-C-sequestration components of existing integrated assessment models.

Finally, each disciplinary component is based on research that our team members have done for other locations, as well as on our early research efforts in Costa Rica. Within the latter, on the economic side we have produced a Harvard Institute for International Development paper for Costa Rica (Boscolo et al. 1999) using district-level land-use data and crude ecological estimates to do a simple version of the early work discussed above. This work has been presented at the National Bureau for Economic Research and the Association of Environmental and Resource Economists. On the ecological side, in general this project will both use and extend (based on the field measurements conducted as part of this study) models of differing complexities that have already been well established. In particular, the CENTURY model is one of the most established ecosystem models in the world. Further, all of the models of $\mathrm{C}$ sequestration that we will consider have been applied (some extensively so) or proposed for application in Costa Rica. 


\section{Goals and Objectives}

Our two overarching, integrated assessment goals have been presented in the Introduction:

(1) to create an integrated, spatially explicit model that predicts how much additional carbon sequestration will occur in Costa Rica if a reward for sequestration is offered; such a model necessarily involves both economic modeling of land use and ecosystem modeling of carbon storage; both will be based on empirical observations, of $\mathrm{C}$ and $\mathrm{N}$ pools and of land use

(2) to contribute to the effective design of the rules that allow carbon sequestration efforts in tropical locations to replace emissions-reduction efforts in more developed countries; to do so, perform sensitivity analysis on the integrated model in order to derive simplified versions of our state-of-the-art disciplinary and integrated models, searching for CER rules that are sufficiently accurate, for sequestration purposes, and low cost, for participation and economic efficiency

\section{As part of achieving these goals, our specific objectives are:}

\section{Collection Of Data}

i. Develop detailed databases on $\mathrm{C}$ and $\mathrm{N}$ stocks in ecosystems throughout Costa Rica, with systematic sampling of the variation within the edaphic, climatic, and land-use conditions.

ii. Extend spatially explicit GIS databases on land use and cover for Costa Rica. Use existing databases from the late 1970s on, and extend them back into the 1940s, 1950s, and 1960s.

iii. Extend spatially explicit GIS databases pertaining to both ecosystem-level conditions and socioeconomic factors relevant for land-use choices, covering significant land-use dynamics.

\section{Advances In Disciplinary Modeling}

i. Advance process-based modeling of $\mathrm{C}$ storage. In particular, advance adaptation of the CENTURY model for simulating $\mathrm{C}$ and $\mathrm{N}$ dynamics in dominant ecosystems of Costa Rica.

ii. Advance empirically-based modeling of $\mathrm{C}$ storage. In particular, advance adaptation of lifezone-type modeling to predict $\mathrm{C}$ storage in mature forests across a range of conditions.

iii. Advance observationally-based economic modeling of land cover, yielding spatially explicit GIS projections. Add a focus on intertemporal elements of land-use choices and processes.

\section{Integration and Policy Evaluation}

i. Integrate the economic and ecological analyses, including within a GIS, for a model linking factors such as payments from an international $\mathrm{C}$ market to land use choices and $\mathrm{C}$ stocks.

ii. Apply this model to evaluate both the baselines underlying a $\mathrm{C}$ market and the effects of various $\mathrm{C}$-market scenarios on local and global sequestration and economic outcomes.

\section{Sensitivity Analysis For Workable Rules}

i. Develop simplified versions of component/integrated models that are easier/cheaper to use.

ii. Evaluate the use of simplified models as the basis for rules for determining $\mathrm{C}$ reward levels in terms of effects on local and global sequestration and economic outcomes and welfare. 


\section{Methods}

As suggested by our specific objectives, our research will consist of three major components:

(1) collect data: field measurements, land-cover data, and socioeconomic factors

(2) do ecosystem modeling of $\mathrm{C}$ sequestration and economic modeling of land use

(3) link models for integrated, spatially explicit policy evaluation and sensitivity analysis

\subsection{Data Collection}

\subsubsection{Inventory of carbon and nitrogen stocks in dominant ecosystems}

To ensure the accuracy of best estimates and reduce the uncertainties of the various model simulations, we plan to measure current $\mathrm{C}$ and $\mathrm{N}$ stocks in dominant ecosystems and land-cover types in a detailed and extensive fashion. This will also help to assess the potential errors arising from the use of simpler and less costly models and estimates. We will assess the spatial variation of these $\mathrm{C}$ and $\mathrm{N}$ stocks, as well their spatial covariances with other environmental variables.

During previous funding periods (including from the Tinker Foundation), the available body of literature regarding $\mathrm{C}$ and $\mathrm{N}$ pools and dynamics in Costa Rican ecosystems has been evaluated. To date, numerous field studies have examined soil $\mathrm{C}$ and $\mathrm{N}$ dynamics in Costa Rica (e.g., Motavalli et al. (1994, 1995), Reiners et al. 1994, Veldkamp 1994). Studies have investigated: the size of various soil organic carbon (SOC) pools (Motavalli et al. 1994); decomposition rates of SOC using both experimental and modeling techniques (Veldkamp 1994, Motavalli et al. 1995); measures of SOC changes after forest-pasture conversion in various soil types (Veldkamp 1994); soil C and N distribution in soil profiles (Martini and Macias 1974, Veldkamp 1994); changes in $\mathrm{C}$ and $\mathrm{N}$ in surface soils $(0-15 \mathrm{~cm})$ of wet forests along an altitudinal gradient (Marrs et al. 1988). In addition, Lieberman and Lieberman (1987) measured tree growth rates and agesize relationships in tropical wet forests in Costa Rica, and Gower (1987) investigated fine root biomass in wet forests and the relationship between fine root biomass and soil nutrient status.

Several additional studies have investigated the impacts of deforestation on ecosystem $\mathrm{C}$ and $\mathrm{N}$ stocks in Costa Rica. Nutrient losses and $\mathrm{N}$ transformation immediately following deforestation have been documented (Ewel at al. 1981, Matson et al. 1987). Changes in soil C and N stocks among sites that include primary and secondary forests as well as pastures have also been documented (e.g., Reiners et al. 1994, Veldkamp 1994, Fernandes and Sanford 1995). In addition, several studies have been carried out to estimate forest growth in tree plantations (e.g., Gonzalez and Fisher 1994, Stuhrmann et al. 1994, Haggar and Ewel 1995).

In addition, long-term studies have been conducted to examine net primary production and nutrient cycling in several agroforestry and cropping systems in Costa Rica (Fassbender et al. 1991, Mazarino et al. 1993). The impacts of tree litter on corn growth (Montagnini et al. 1993) as well as the impacts of different cropping practices and/or fertilization on soil $\mathrm{N}$ and $\mathrm{C}$ of corn fields were also investigated (Haggar et al. 1993, Reeves et al. 1997). However, no studies have yet been conducted to explicitly quantify soil and aboveground $\mathrm{C}$ and $\mathrm{N}$ pools at the ecosystem scale across the range of climatic, edaphic, and land-use conditions encountered in Costa Rica. 
Finally, previous regional calculations consider the impact of land-use change on $\mathrm{C}$ dynamics, including in Costa Rica (Brown 1997, Houghton et al. 1991, Hall et al. 1985). However, these tend to use measurements of $\mathrm{C}$ pools and dynamics made elsewhere in the tropics and/or are not detailed enough in their determination of the various components of $\mathrm{C}$ and $\mathrm{N}$ stocks to be of great use for ecosystem-scale models such as CENTURY. Hughes et al. (in press a.) noted the substantial discrepancies that can result between regional estimates of $\mathrm{C}$ and $\mathrm{N}$ pools that are made with generic $\mathrm{C}$ and $\mathrm{N}$ values calculated from studies outside of the tropical region in question, versus those made with region-specific measures of $\mathrm{C}$ and $\mathrm{N}$ pools and dynamics. In addition, while forest inventory data exists for Costa Rica, such data often includes only measures of commercial or industrial products (e.g., saw-wood, veneer logs, pulpwood) and does not include non-merchantable species or sizes, small or defective trees, branches, bark, leaves, stumps, roots, surface litter, or soil organic matter. Such ecosystem components can account for large portions of total $\mathrm{C}$ and $\mathrm{N}$ pools, and may vary in ways that are not easily predicted from measures of large tree or bole biomass (Kauffman et al. 1998b). Without detailed, regionspecific measures of aboveground and soil $\mathrm{C}$ and $\mathrm{N}$ pools, regional estimates of the dynamics of such pools will be superficial at best, and inaccurate and misleading at worst. In summary, while the numerous studies relevant to $\mathrm{C}$ and $\mathrm{N}$ dynamics conducted to date in Costa Rica will undoubtedly aid the construction of $\mathrm{C}$ and $\mathrm{N}$ budgets in ecosystems across that nation, at present such studies are not sufficient to accurately estimate regional $\mathrm{C}$ stocks in vegetation and soils.

These facts indicate the need for a systematic selection of field sites for sampling aboveground and soil pools of $\mathrm{C}$ and $\mathrm{N}$ in order to obtain unbiased estimates at the national scale. In this study, field data will be collected to address this need for a systematic approach. First, all sites to be sampled for aboveground and soil $\mathrm{C}$ and $\mathrm{N}$ will be selected using the extensive and detailed GIS databases of climatic, edaphic, and land-use history characteristics in Costa Rica to provide the widest and most pertinent range of sampling points across Costa Rica. Second, results from sites sampled along these gradients will be combined with available GIS databases to estimate current $\mathrm{C}$ and $\mathrm{N}$ stocks in ecosystems across Costa Rica. Third, these field measures will be used to validate our ecological modeling efforts, which constitute one component of the integrated set of models that we are designing (see modeling sections below). In addition, by creating this detailed and comprehensive dataset regarding $\mathrm{C}$ and $\mathrm{N}$ pools across Costa Rica, we will be able to effectively utilize, in both process-level and empirical modeling efforts, the extensive but rather divergent assemblage of data collected in previous ecological studies conducted in Costa Rica (see above); our $\mathrm{C}$ and $\mathrm{N}$ pool database will provide the structural basis through which such previously collected, and highly informative, data can be incorporated into our modeling efforts.

We propose to sample $\mathrm{C}$ and $\mathrm{N}$ pools in at least 75 sites that span the range in edaphic, climatic, and land-use characteristics encountered in Costa Rica. These sites include mature forests, dominant forms of management (e.g., pastures, banana and coffee crops), and secondary forests of various ages. Mature forest sites will be selected to encompass the range in forest types encountered in Costa Rica (e.g., tropical dry, moist, and wet forests), as defined by the life zone system (Holdridge et al. 1971). In addition, our sites will represent the edaphic variability encountered in each life zone class. This variability ranges from fertile Udolls and Ustolls of alluvial origin to moderatately fertile, ash derived Andepts, to relatively infertile Humults and 
Udults. Finally, sites will be selected and sampled within each life zone class which represent both dominant land-use types and phases of forest recovery (i.e., secondary forests) encountered in that life zone class. Mature forest $\mathrm{C}$ and $\mathrm{N}$ pools will be used as hypothesized maxima for $\mathrm{C}$ and $\mathrm{N}$ sequestration. Actively managed sites (e.g., pastures and croplands) will be used as hypothesized minima for $\mathrm{C}$ and $\mathrm{N}$ sequestration, and secondary forests will provide information regarding potential rates of $\mathrm{C}$ and $\mathrm{N}$ accumulation following abandonment. In this way we will determine the influence of soil type and climate on $\mathrm{C}$ and $\mathrm{N}$ dynamics and the interplay between land-use change and those variables. Costa Rica is an ideal region for this work because of the availability of extensive and detailed GIS databases that give us the ability to locate, in an unbiased manner, sites that maximize the relevance of field-based sampling for modeling efforts. Available GIS databases will also allow us to extrapolate, in an informed and appropriate manner, field estimates of $\mathrm{C}$ and $\mathrm{N}$ across relevant areas of the landscape.

Aboveground and soil pools of $\mathrm{C}$ and $\mathrm{N}$ will be sampled using a nested plot design. A large plot ( $0.9 \mathrm{ha}$ ) will be established at each site (Figure 2 below). Within this plot we will sample all of the constituent biomass components of that particular land-cover type. For example, we will measure the diameter at breast height ( $\mathrm{dbh}$ ) and record the species of all living and dead trees $>10 \mathrm{~cm}$ dbh that occur in the plot. Living and dead trees and vines $<10 \mathrm{~cm}$ dbh will sampled in fifteen $2 \times 10 \mathrm{~m}$ subplots distributed across the larger plot. Understory biomass components (e.g. litter, woody debris, herbaceous vegetation) will be measured at the subplot level as well.

Biomass of each component will be calculated using a combination of allometric equations and destructive sampling techniques (for example, see Table 1 below). We have developed such models during previous studies of $\mathrm{C}$ and $\mathrm{N}$ dynamics in both the Amazon Basin and tropical Mexico (Kauffman et al. 1995 , Hughes et al. a. in press, and Hughes et al. b. in press), and will add to this suite of equations to ensure that calculations of biomass are specific to, and appropriate for, the biomass pools encountered across sampling areas in Costa Rica. From these biomass measures, we will calculate $\mathrm{C}$ and $\mathrm{N}$ pools from $\mathrm{C}$ and $\mathrm{N}$ concentrations determined from tissue samples that will be collected for each respective biomass component. Soil pools will be determined through collection of soil samples to a $1 \mathrm{~m}$ depth; $\mathrm{C} \%$ and $\mathrm{N} \%$ as well as bulk density will be determined for each sample at each site. Following their collection from the field, all soil and plant tissue samples will be transported to the Univ. of Colorado where $\mathrm{C}$ and $\mathrm{N}$ will be determined using a Carlo-Erba NA Series $1500 \mathrm{CN}$ analyzer.

Previous work has shown this methodology to be an effective and efficient means of quantifying dynamics of aboveground and soil $\mathrm{C}$ and $\mathrm{N}$ pools in response to land-use change in the Brazilian Amazon (Kauffman et al. 1995, Kauffman et al. 1998a, Hughes et al. in review, Cummings et al. in review), seasonally dry forests of Jalisco, Mexico (Kauffman et al. in prep.), and moist tropical forest systems of Los Tuxtlas, Mexico (Hughes et al. in press at Ecology and Hughes et al. in press at Ecological Applications). This methodology provides not only total pools of $\mathrm{C}$ and $\mathrm{N}$, but also measures of each of the various biomass components (e.g., trees, litter, wood debris, and herbaceous plants). Such detail is invaluable for the calibration and validation of our ecological models, since these biomass components vary widely with respect to their rates of production and decomposition, and levels of combustion. Thus, such detail permits more accurate calculation of average process rates and/or the use of ecological models requiring more detailed process inputs. 


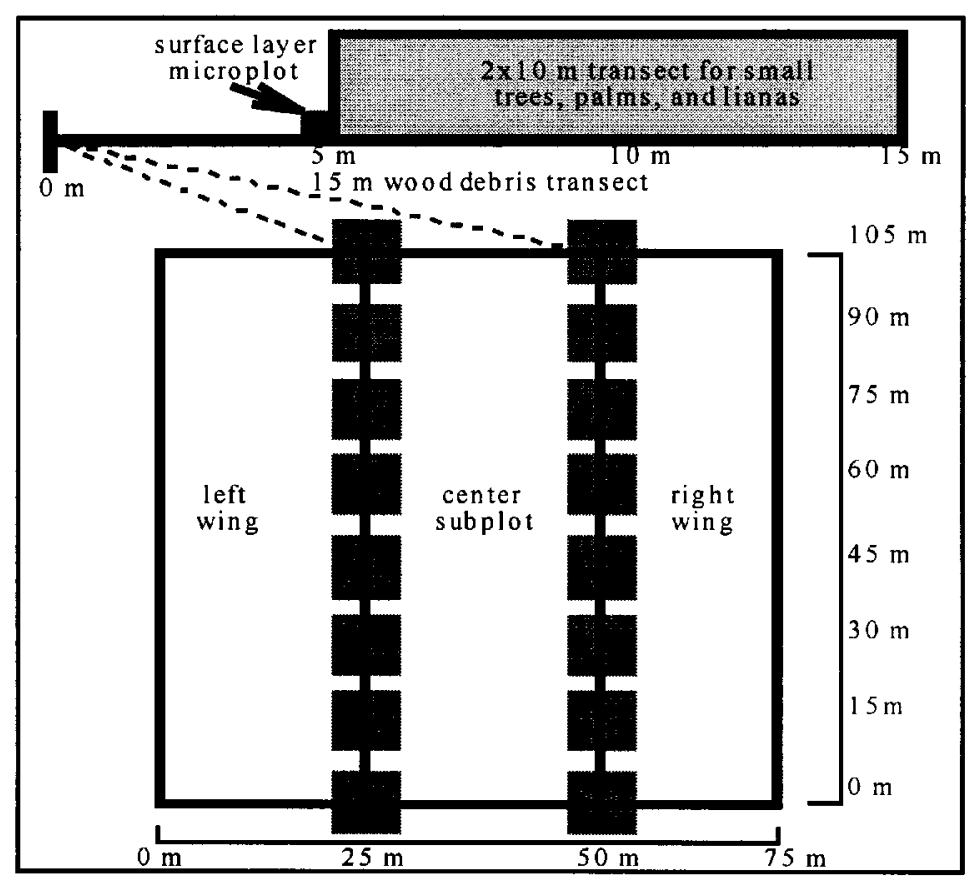

Figure 2. Example of plot layout to sample total aboveground biomass in primary forest sites of Los Tuxtlas. Trees $>10 \mathrm{~cm}$ diameter at breast height ( $\mathrm{dbh}$ ) are measured within the central subplot of the plot; trees $>30 \mathrm{~cm} d \mathrm{dbh}$ are measured within the entirety of the plot. Trees and lianas $<10 \mathrm{~cm}$ diam. dbh are measured within each subplot distributed throughout the plot. Woody debris are measured along planar transects distributed throughout the plot, and litter and understory herbaceous (i.e. the surface layer) biomass is measured within microplots.

TABLE 1. Equations to determine components of aboveground biomass of secondary forest sites in the Los Tuxtlas Region. All biomass values are expressed as dry weight $(\mathrm{Mg})$.

\begin{tabular}{|c|c|c|c|}
\hline Parameter & Equation & $\overline{\mathrm{C} . \mathrm{E}}$ & $\overline{\overline{R^{2}}}$ \\
\hline Height of trees $>10 \mathrm{~cm} \mathrm{dbh*}$ & $=4.722 \ln \left(\mathrm{D}^{2}\right)-13.323$ & none & 0.70 \\
\hline Biomass; trees $>10 \mathrm{~cm}$ dbh $\dagger$ & $=\left(\exp \left(-2.409+0.9522 \ln \left(\mathrm{D}^{2} \mathrm{H} \mathrm{Sg}\right)\right)\right) \mathrm{CF} / 10^{3}$ & 1.03 & 0.99 \\
\hline Biomass; Cecropia $>10 \mathrm{~cm}$ dbh (wood) $\ddagger$ & $=\left(\exp \left(-3.78+0.95 \ln \left(\mathrm{D}^{2}\right)+1.00 \ln (\mathrm{H})\right) / 10^{3}\right.$ & none & 0.88 \\
\hline Biomass; Cecropia $>10 \mathrm{~cm}$ dbh (leaf) $\ddagger$ & $=\left(-0.56+0.02\left(\mathrm{D}^{2}\right)+0.04(\mathrm{H})\right) / 10^{3}$ & none & 0.98 \\
\hline Biomass; standing dead trees $>10 \mathrm{~cm}$ dbh $*$ & $=\check{s}\left((\mathrm{D} / 2)^{2}\right) \mathrm{H}(0.42)$ & none & none \\
\hline Biomass; trees $<10 \mathrm{~cm}$ dbh $*$ & $=\left(\exp \left(4.9375+1.0583 \ln \left(\mathrm{D}^{2}\right)\right)\right) \mathrm{CF} / 10^{6}$ & 1.14 & 0.93 \\
\hline Biomass; dead trees $<10 \mathrm{~cm}$ dbh * & $=\left(\exp \left(4.6014+1.1204 \ln \left(\mathrm{D}^{2}\right)\right)\right) \mathrm{CF} / 10^{6}$ & 1.11 & 0.95 \\
\hline Biomass; palms * & $=\left(\exp \left(3.6272+0.5768 \ln \left(\mathrm{D}^{2} \mathrm{H}\right)\right)\right) \mathrm{CF} / 10^{6}$ & 1.02 & 0.73 \\
\hline Biomass; dead palms * & $=\left(\exp \left(-0.5285+0.9907 \ln \left(\mathrm{D}^{2} \mathrm{H}\right)\right)\right) / 10^{6}$ & none & 0.98 \\
\hline Biomass; lianas $\S$ & $=\left(10^{\gamma}(0.12+0.91\right.$ LOG10(BA $\left.\left.)\right)\right) / 10^{3}$ & none & 0.82 \\
\hline Biomass; tree leaves II & $=\exp \left(-1.897+0.836 \ln \left(\mathrm{D}^{2} \mathrm{H}\right)\right) / 10^{3}$ & none & 0.85 \\
\hline Biomass; sapling wood * & $=\exp \left(4.7472+1.0915 \ln \left(\mathrm{D}^{2}\right)\right) / 10^{6}$ & 1.13 & 0.93 \\
\hline Biomass; sapling leaves * & $=\exp \left(3.0473+.07778 \ln \left(\mathrm{D}^{2}\right)\right) / 10^{6}$ & 1.45 & 0.706 \\
\hline Biomass; liana leaves $\S$ & $=((0.109 \mathrm{BA})-0.376) / 10^{3}$ & none & none \\
\hline Biomass; wood debris $2.45-7.6 \mathrm{~cm}$ diam. \# & $=\operatorname{Sg}\left(\left(S^{2} \mathrm{~N} \mathrm{~S} \mathrm{Cs} d^{2}\right) / 8 \mathrm{~L}\right) \times 10^{2}$ & none & none \\
\hline Biomass: wood debris $>7.6 \mathrm{~cm}$ diam. \# & $=\mathrm{Sg}\left(\left(\breve{s}^{2} \operatorname{sumD}^{2} \mathrm{~S} C \mathrm{C} \mathrm{d}^{2}\right) / 8 \mathrm{~L}\right) \times 10^{2}$ & none & none \\
\hline
\end{tabular}

Note : Definitions for symbols used in the above equations: $\mathrm{D}=$ diameter breast height $(\mathrm{cm})$;

$\mathrm{Cs}=$ slope correction factor (square root of $\left(1+(\% \text { slope } / 100)^{2}\right) ; \mathrm{Sg}=$ specific gravity of $\operatorname{wood}\left(\mathrm{g} / \mathrm{cm}^{3}\right)$;

$\mathrm{N}=$ number of pieces of wood debris intersected per transect; $\mathrm{BA}=$ basal area $\left(\mathrm{cm}^{2}\right) ; \mathbf{H}=$ height $(\mathrm{m})$;

$\mathrm{S}=$ secant of wood debris tilt; $\mathrm{d}=$ quadratic mean diameter of wood debris $(\mathrm{cm}) ; \mathrm{L}=$ transect length $(\mathrm{cm})$;

$\mathrm{CF}=$ correction factor $=\exp (\mathrm{MSE} / 2) ; \operatorname{sumD}^{2}=$ sum of wood debris diameters ${ }^{2}\left(\mathrm{~cm}^{2}\right)$;

Symbols following each parameter term indicate source: $*=$ this study; $\dagger=$ Brown and Lugo

1989; $\ddagger=$ Uhl et al. 1988; $\S=$ Putz 1983; I = Crow 1978; \# = Van Wagner 1964. 


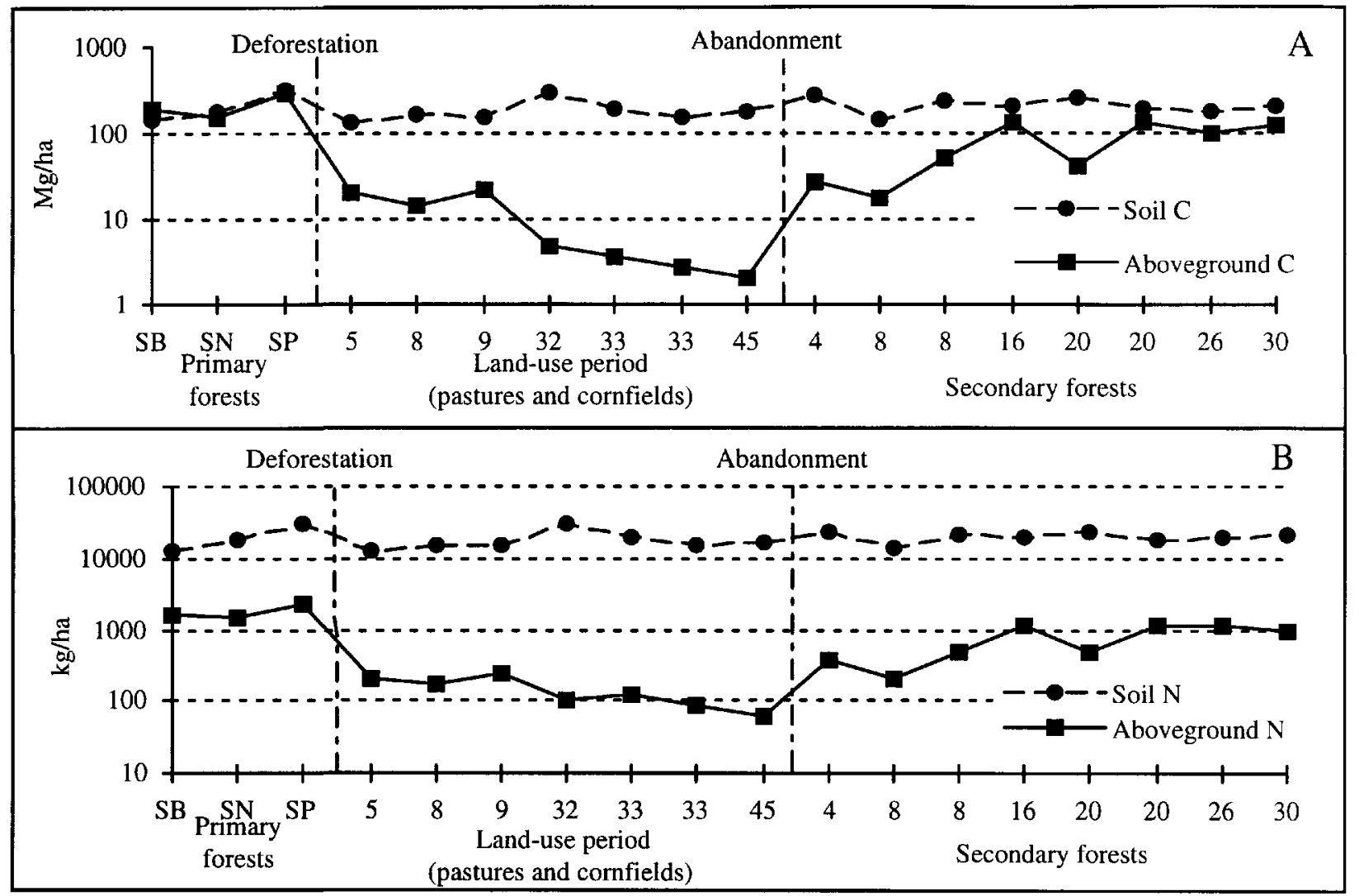

Figure 3. Dynamics of $\mathrm{C}(\mathrm{A})$ and $\mathrm{N}(\mathrm{B})$ in aboveground and soil pools along a land-use gradient in Los Tuxtlas. Values are presented using Log scales. In the case of pastures and cornfields, values along the $\mathrm{x}$-axis represent the number of years of land-use following deforestation. In the case of secondary forests, values along the $x$-axis represent the number of years of succession following abandonment. Hughes et al. (b. in press).

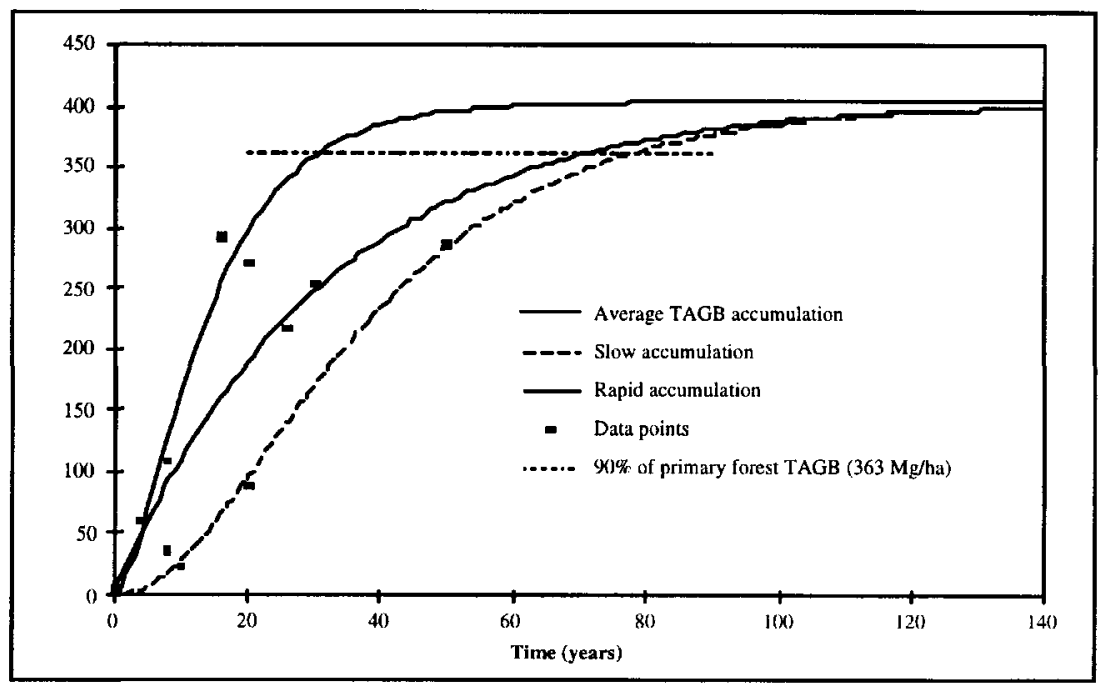

Figure 4. Estimates of mean annual aboveground biomass accumulation during secondary succession in Los Tuxtlas. Accumulation rates predicted using the Richards function (Cooper 1983). Maximum total aboveground biomass (TAGB) defined as the average TAGB of primary forests sampled in the region (i.e., $403 \mathrm{Mg} / \mathrm{ha}$ ). Results indicate that secondary forests would reach TAGB levels equivalent to those of primary forests in the region after 73 years. Rapid accumulation is in secondary forest sites with short periods of land use prior to abandonment. Slow accumulation is in sites with long periods of land-use prior to abandonment (Hughes et al. b. in press). 
In the heavily deforested tropical region of Los Tuxtlas, Mexico, conversion of primary forests to pastures or cornfields resulted in declines of $95 \%$ and $91 \%$ of aboveground $\mathrm{C}$ and $\mathrm{N}$ pools, respectively (Hughes et al. a. in press). In contrast, soil pools of $\mathrm{C}$ and $\mathrm{N}$ remained relatively stable among sites located along the land-use gradient of this region (Figure 3 ). In addition, biomass accumulation by secondary forests in the Los Tuxtlas Region was shown to be rapid; results indicated that secondary forests would attain aboveground biomass levels equivalent to those of primary forests of the region after 73 years of succession (Figure 4). However, rates of accumulation were very much constrained by the duration of prior land use; longer land-use periods of land use resulted in slower rates of accumulation (Hughes et al. b. in press).

The above findings represent examples of the data that we propose to generate for regions across Costa Rica in a manner that will capture the variation in $\mathrm{C}$ and $\mathrm{N}$ pools and dynamics in response to the edaphic, climatic, and land-use characteristics that are encountered. In addition, all fieldwork efforts will be conducted in close coordination with the Tropical Science Center in Costa Rica. Approximately 25-30 sites will be sampled each year over the course of 3 months of field work (i.e., 75 to 90 sites during the entirety of the study).

The overriding objective of this research goals is to create highly accurate estimates (down to the biomass component-level at each site) of $\mathrm{C}$ and $\mathrm{N}$ pools across environmental and land-use gradients in Costa Rica (i.e. mature forests, managed sites, and secondary forests). These results will be used to validate and assess the accuracy of the ecosystem models (Century, LZS, and any others), will provide the necessary framework in which to incorporate and use relevant data from previously published ecosystem-scale research in both our process-level and empirical models, and will provide the necessary baseline data for $\mathrm{C}$ storage values used in economic calculations.

\subsubsection{Data on land use and land cover}

To increase the quality of our analyses of land-use choices and their implications for land cover, we will extend our existing efforts to acquire and process both land-use and land-cover data. In order to improve our understanding of land-use choices relevant for $\mathrm{C}$ sequestration over a significant period of time and development, we will extend our existing data sets back in time.

While data sets certainly exist for other tropical, forested countries, the potential in Costa Rica for excellent data of the sort necessary for our analyses is extraordinary, in particular given several institutional initiatives concerning geographic data. Our team's earlier work provides a detailed and comprehensive data set (see Table 2 below), which is an important base for the work we propose here. However, given the difficulty of the inferences we want to make, including the estimation of rules that are useful for other countries, we will substantially increase the quality and scope of these data sets, making use of Costa Rica's available land-use and land-cover data.

To increase quality, we will complete the processing (already started at the Earth Observation Systems Laboratory (EOS-Lab) of the Department of Earth and Atmospheric Sciences at the University of Alberta) of the 1978/1979 data sets acquired through our Tinker Foundation grant. This will produce a data set compatible with 1986 and 1997 forest-cover datasets. To increase scope, we will extend our data sets back in time through the acquisition of 1945 data (processed 
into paper maps, from aerial photos) for portions of Costa Rica that we do not already have. We will also process the paper maps we do have for both the 1945 and 1960 datasets. Finally, we will develop pixel samples of the entire GIS dataset (as done in Sanchez-Azofeifa (1996, 1999a) for assessment of tropical deforestation processes). This permits more accurate, pixel-level analysis, including the integration of spatially explicit ecological and economic data.

Table 2 - Data Collected To Date (some still to be processed by the EOS-Lab, University of Alberta)

\begin{tabular}{|l|l|l|l|l|}
\hline & Land Use Data & & & \\
\hline Year & Area Covered & Description & Scale & Source \\
\hline 1945 & Guanacaste, Central & forest/not & $1: 24,000$ & IGN, paper maps/aerial photos \\
\hline 1960 & Costa Rica & forest/not & $1: 50,000$ & IGN, paper maps \\
\hline 1966 & Costa Rica & forest/not & $1: 50,000$ & IGN, paper maps \\
\hline 1979 & Costa Rica & land uses & $1: 200,000$ & IMN and satellite images \\
\hline 1984 & Costa Rica & land uses & $1: 200,000$ & IGN \\
\hline 1986 & Costa Rica & land cover & $1: 250,000$ & FONAFIFO \\
\hline 1992 & Costa Rica & land uses & $1: 200,000$ & IMN \\
\hline 1992 & Costa Rica & forest/not & $1: 250,000$ & EOS-Lab, Alberta \\
\hline 1997 & Costa Rica & forest/not & $1: 250,000$ & FONAFIFO/ EOS-Lab, Alberta \\
\hline
\end{tabular}

\begin{tabular}{|l|l|l|l|l|}
\hline & Ecological Data & & & \\
\hline Years & Variable & Description & Scale/Unit & Source \\
All & lifezones & 12 zones & $1: 200,000$ & Tropical Science Center \\
\hline$A l l$ & soils & 8 soil types & $1: 200,000$ & FAO \& Agricultural Ministry \\
\hline$A l l$ & topography & & $1: 200,000$ & IGN \\
\hline
\end{tabular}

\begin{tabular}{|c|c|c|c|c|}
\hline \multicolumn{5}{|c|}{ Economic Data } \\
\hline Years & Variable & Description & Unit & Source \\
\hline $1950,1984,1996$ & population & total, urban & district & Population Census \\
\hline 1963,1973 & population & total & province & Population Census \\
\hline $1824-1996$ & population & total & national & IHS and MIDEPLAN \\
\hline $\begin{array}{l}\text { various years within } \\
1950-1986\end{array}$ & agricultural areas & $\begin{array}{l}\text { coffee, sugar, } \\
\text { cattle, bananas }\end{array}$ & county & Agricultural Census \\
\hline 1990,1997 & transport costs & $\$$ & regional & WAU and CNP \\
\hline 1985 & roads & GIS, w/history & & \\
\hline ranges of years & incentives & ha w/payments & district & FONAFIFO \\
\hline $1979,1986,1997$ & protected areas & ha (4 types) & district & FONAFIFO \\
\hline $1950-1997$ & export crop prices & $\$$ & & BCCR \& MIDEPLAN \\
\hline $\begin{array}{l}\text { various years within } \\
1950-1997\end{array}$ & crop yields & $\begin{array}{l}\text { coffee,sugar, } \\
\text { cattle, bananas }\end{array}$ & $\begin{array}{l}\text { county, } \\
\text { province }\end{array}$ & various \\
\hline various, $1930-1997$ & production costs & $\begin{array}{l}\text { coffee,sugar, } \\
\text { cattle, bananas }\end{array}$ & regional & various \\
\hline 1997 & land value & all Costa Rica & district & Tropical Science Center \\
\hline $1958-1978$ & pasture value & all Costa Rica & county & BCCR \\
\hline $1959-1978$ & undeveloped value & all Costa Rica & county & BCCR \\
\hline
\end{tabular}

Abbreviations: IMN-National Meteorological Institute; IGN-National Geographic Institute; FONAFIFO-Forestry Ministry; MIDEPLAN - Ministry of development and planning; IHS-International Historical Statistics; CNP domestic producer board; BCCR-Central Bank of Costa Rica; WAU-Wageningen Agricultural University 


\subsubsection{Data on factors that affect land-use choices}

To improve our best estimates of the effects of important factors on land use, we will extend our existing efforts to acquire and process data on such factors. In particular, given that $\mathrm{C}$ payments are our policy focus, to improve our estimates of the effects of changes in such payments, we will extend our existing data sets regarding land value and the returns from different land uses.

By way of background, deforestation in Costa Rica has been significant (Sader and Joyce 1988, Centro Cientifico Tropical 1982, Sanchez-Azofeifa et al 1999b). Sanchez-Azofeifa and QuesadaMateo (1995) found that deforestation leads to environmental degradation including species loss, erosion of top soil and siltation. They identified the primary causes of deforestation as expansion of the agricultural frontier in critical and fragile areas, and urban expansion. Costa Rica has also had high population growth. Not surprisingly, then, Costa Rica has taken steps to protect areas of valuable natural and scenic habitats. Currently, $29 \%$ of Costa Rica's territory is under some degree of protection (Sanchez-Azofeifa et al. 1999a). This, too, affects land-use choices (for instance, Sanchez-Azofeifa et al. (1999b) indicate the value of reserves in curbing deforestation).

Starting from this background, some studies of Costa Rican land use have taken demographic tacks (e.g., Harrison 1991, Rosero-Bixby and Palloni 1996). However, such a focus often leads to inadequate consideration of non-population factors that affect land-use choices (such a focus is also common in cross-country empirical efforts, e.g. Rudel 1989). Our group's preliminary work suggests that land with certain physical characteristics is more vulnerable to deforestation, and that road density is an important factor in deforestation. Given the effects of deforestation, understanding the effects of such factors on deforestation is important for the sustainability of Costa Rican development. In addition, it is crucial for developing any carbon-sequestration baseline. Finally, an understanding of such factors' effects can be of relevance to other countries.

Many early analyses of land use, though, were cross-country analyses limited by data availability (Lugo et al. 1981, Allen and Barnes 1985). Recently, economists have been able to expand data sets on important factors by working within particular countries (Pfaff $(1995,1999)$, Chomitz and Gray 1996, Cropper et al. 1999). Even by these standards, the data potentially available for Costa Rica is abundant. Also, our earlier efforts provide an extensive data set (see Table 2). While this does provide a base, again we note that in order to make high-quality inferences, we will increase both the quality and scope of these data sets, making use of Costa Rica's potential.

In increasing quality and scope, we will focus on acquiring and processing improved economic data for measuring the returns to different land uses: prices, yields, production costs, transport costs across time and space. To this end, we are working with the Costa Rican Ministry of Agriculture and other contacts in agriculture. For instance, we will use historical records of the Costa Rican transportation network to create GIS maps of the main network at several points before 1985. Along with this data, we will utilize data on the value of land itself. This will allow us to complement our direct estimates of returns with a hedonic estimation of land values. We will also work at both the more aggregated, district level and the more disaggregated, pixel level. 


\subsection{Ecosystem and Economic Modeling}

\subsubsection{Ecosystem Modeling of Carbon Sequestration}

Process-based models

In this study, the CENTURY model will be further calibrated and validated using measurements of $\mathrm{C}$ stocks in various ecosystems in Costa Rica collected within the field campaign described above. This will permit simulation of $\mathrm{C}$ stocks and their dynamics in ecosystems across all of Costa Rica when coupled to simulations of land cover change from an economic model (see Section 3.2.2) estimated from supporting GIS databases described above. These integrated simulations will generate a $\mathrm{C}$ supply function for Costa Rica and other policy analyses.

Many models have been developed to simulate the dynamics of $\mathrm{C}$ stocks in various ecosystems. Experiments have been conducted to evaluate the performance of these models in simulating changes of soil organic $\mathrm{C}$ and standing biomass across a wide range of environmental and management conditions (e.g., VEMAP 1995, Smith et al. 1997). Their results inform the selection of models for particular conditions. The final decision on which model to use for a specific project depends on factors such as model performance, data requirement, and previous experiences. We have selected the CENTURY model, developed at Colorado State University, as the process-based model for this project on the basis of model robustness across a wide range of conditions, as well as our previous experiences with the model in Costa Rica.

The CENTURY model is one of the most established ecosystem models in the world (see Parton et al. 1987, Schimel et al. 1997). This model simulates C, N, P, and S cycles in various ecosystems, including pastures, forests, crops, and savannas, with the capability of modeling the impacts of management practices (e.g., fertilization, cultivation) and natural disturbances such as fire and hurricane (Parton et al. $(1987,1993)$ ). The model has been tested extensively against field measurements from various ecosystems around the world (e.g., Parton et al. 1993, Schimel et al. 1994, Smith et al. 1997) and used for biogeochemical simulation purposes at the regional, continental, and global scales (e.g., Schimel et al. 1994, VEMAP 1995; Schimel et al. 1997).

For comparison with simpler, empirically-based bio-ecological models, note that the major inputs for the monthly-time-step version of CENTURY include (Cole et al. 1993): monthly average maximum and minimum air temperature, monthly precipitation, lignin content of the plant material, plant $\mathrm{N}$ content, soil texture, atmospheric and soil $\mathrm{N}$ inputs, initial soil $\mathrm{C}$ and $\mathrm{N}$ levels, and management practices such as fertilization. A modeler must choose how to generate such input parameters, through fieldwork, existing GIS databases or the literature (the fieldwork proposed above will be of value here). Corresponding to this demand for inputs, the model generates a rich set of outputs. For instance, the outputs most relevant to $\mathrm{C}$ dynamics of an ecosystem can be grouped into: above- and below-ground primary productivity, above- and below-ground standing biomass, $\mathrm{CO}_{2}$ emissions during litter decomposition, $\mathrm{C}: \mathrm{N}$ ratios of plant tissues, $\mathrm{C}$ removed during events such as grazing and harvesting, and soil $\mathrm{C}$ pool sizes. 
This project has a headstart on applying this modeling approach to all of Costa Rica, as we have already successfully adopted the CENTURY model to the Atlantic Zone of Costa Rica, to simulate the dynamics of $\mathrm{C}$ and $\mathrm{N}$ in major ecosystems, including primary forests, secondary forests, pastures, and banana plantations (Liu et al. (1999a, 1999b), Reiners et al. 1999). We have also already coupled the CENTURY model with the expert system PASTOR (designed for the optimization of pasture systems in Costa Rica with physical, economic, and environmental constraints) to account for the impacts of edaphic, biotic, and management factors on $\mathrm{C}$ and $\mathrm{N}$ cycling in pastures (Liu et al. 1999c). Methods were developed for site-scale simulations using GIS databases and statistical techniques (Liu and Reiners 1999; Reiners et al. 1999).

For instance, consider the dramatic conversion of forests to agricultural lands during the last two decades in certain regions of Costa Rica. In the Atlantic Zone, where forest-pasture conversion was dominant, about $44 \%$ of the non-swamp forest was converted to agricultural land from 1979 to 1996 (Reiners et al. 1999). As an example of the modeling to be done in our project, the modified CENTURY model successfully captured the dynamics of soil organic matter along a chrono-sequence of pastures converted from primary forests (Liu et al. 1999b; Figure 5 below).

Extending this regional work, we will further calibrate and validate the CENTURY model with field measures of $\mathrm{C}$ stocks collected from the various ecosystems/land use gradients across Costa Rica. The output will be a mapping that links the observed characteristics of an area to $\mathrm{C}$ sequestration which can then be compared to both additional field data and other models (see Model Testing and Deployment below). Such a mapping will be applied to all of Costa Rica, and coupled with the outputs of economic modeling for integrated policy analyses.

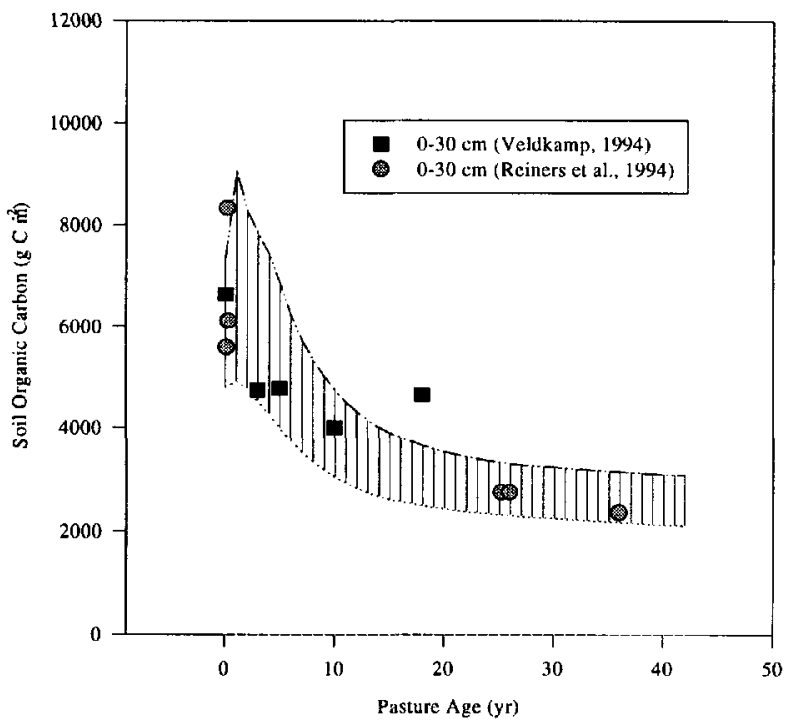

Figure 5. Comparison of predicted and measured dynamics of soil organic matter along a chronosequence of pastures converted from primary forests in the humid tropics of Costa Rica (from Liu et al. 1999b). The upper boundary of the prediction was based on high-input scenario with a passive soil organic $\mathrm{C}$ pool size of $3000 \mathrm{~g} \mathrm{C} \mathrm{m}^{2}$ (Veldkamp 1994). The lower boundary of the prediction was based on the low-input scenario of forest residue with a passive soil organic $\mathrm{C}$ pool size of $2300 \mathrm{~g} \mathrm{C} \mathrm{m}^{-2}$ (Veldkamp 1994). 
Empirically-based models

Empirical models are an important counterpart to process modeling within our overall approach. Process models have the advantage that they can be used, with caution, for novel or unobserved situations, such as future climate changes, or plantations with artificial mixtures of species. This is possible because the variable predicted ( $\mathrm{C}$ storage) changes as a result of basic ecological processes (primary production, decomposition, nutrient cycling, soil hydrology). In contrast, calibrated empirical models are best used as interpolators, in situations close to those observed.

In this context, empirical models can be thought of as organized generalizations of the observed relationships between known or easily-measured environmental variables and ecosystem properties. In Costa Rica, the World Life Zone System of Ecological Classification (Holdridge Life Zone System, or LZS) has long been used to organize information about vegetation. While there has been controversy over the use of this system in predictive modeling for climate change, it is a robust empirical way of organizing extant data in Costa Rica, where scientists familiar and experienced with the system continue to use it in a variety of applications, including $\mathrm{C}$ sequestration studies. Published LZS maps are available for Costa Rica, and can be linked to maps of soils, topography and actual land use. While the LZS was developed in Costa Rica, it has been applied worldwide (Holdridge et al. 1971) and can be used as a guideline for organizing vegetation data generally. Costa Rica contains 12 life zones out of 130 recognized worldwide.

At its fundamental (i.e. first, or bioclimatic) level, the LZS uses basic climatological data from standard meteorological information. This level estimates NPP from actual evapotranspiration (itself a function of biotemperature and moisture), and the relationship of primary productivity to fundamental climatological data has been quantified (Holdridge et al. 1971). Additional levels in the LZS classification system also take into account soils and disturbance regime (or time since disturbance). Thus, when fully parameterized, this system will create a multidimensional matrix based on biotemperature, moisture (from precipitation measurements), soils and land use.

Currently, this matrix is the organizing principle for much extant Costa Rican data, and can serve as a template for organizing additional information on $\mathrm{C}$ pools and fluxes. Given such organized information, one may then more fully parametrize the LZS model, with not only climate but also soils variables being used within multiple regression models (Tosi 1997). This study will include such regressions, thereby extending the parametrized LZS model (the soils and rainfall distribution measures will be deviations from average climatic conditions). Thus, one of our ecological outputs will be LZS-based regressions relating primary productivity and C storage in vegetation and soils to not only climatological but also soil and disturbance conditions.

Since our process model is also mainly driven by climate and soils information, we can check the results of the two approaches with common inputs. The LZS-based system will be a key tool for understanding the broad-brush relationships between environmental factors and plausible $\mathrm{C}$ increments and storage levels. It will also link our work with the indigenous scientific paradigm and extant data bases. Finally, when proposed manipulations are near-term or similar to existing observed situations, it gives us a clear empirical way of both reality checking more complex process-model results and explaining them in terms of the basic environmental-C relationships. 
Model Testing and Deployment

For CENTURY, data from $50 \%$ of the field sites will be used to calibrate the model. Then both the CENTURY and LZS models (and any others) will be validated using the field measurements (with either all of the data or the remaining 50\%). The resulting improved models will plug into our first IA goal, the C-sequestration supply function for Costa Rica. They will also provide the starting point for our search for simplified models which retain predictive power, to guarantee sequestration outcomes, but are easier and cheaper to use for other countries, raising efficiency.

The derivation of these simpler models (or rules) for actual $C$ markets, from our state-of-the-art models, is itself a significant research undertaking. For instance, if CENTURY gives the best absolute predictions of field $\mathrm{C}$ measurements, one might derive simpler but still accurate versions on the basis of the simulated results of the full model. This would involve multiple-regression analysis, sometimes called meta-modeling because simpler models are being developed from simulated results. Such techniques have proven effective elsewhere (Parton et al. 1993, Schimel et al. 1994). However, whether a version with few variables, i.e. requiring few inputs, can yield high absolute accuracy is an open, and important, question. Another, relative question is whether a simplified version of a complex model can provide better $\mathrm{C}$ predictions than a simpler model.

\subsubsection{Economic Modeling of Land Use}

We will produce state-of-the-art empirical economic models of tropical land use across Costa Rica using both district- and pixel-level observations. We note that the estimated models will be based on observations of actual land-use choices. We will advance the economic modeling of land use, particularly through our empirical approach to dynamics, and through the time period that we will consider. This analysis will also provide one component of our integrated models.

Certainly we must start with a conception of land-use dynamics in Costa Rica (such as provided as background in section 3.1.3, and by many others, e.g. Hall et al. 1985, Lutz and Daly 1990). In our theoretical model, a landowner solves a dynamic optimization problem to choose the use for each plot at each point in time. Landowners choose the land-use path with greatest returns. Returns depend on land characteristics, current and past land use, prices and yields of different crops, costs of production and access to markets, costs of changing land uses, and expected future values of these factors. The landowner's problem features uncertain future returns, credit constraints, insecure tenure, limited information, bounded rationality, and irreversible actions.

While a perfect empirical model would exactly predict the land choices at each point in time, in reality we cannot observe all the factors affecting the land owner (including his perceptions). Thus, from our theoretical model we must derive empirical/econometric models which focus on properly estimating the effects of the key observable factors, while allowing for unknown effects of factors that should matter to land use but for which we lack information. All of the coefficients are estimated from the observed data, with standard errors (we test our assumed error structure).

We econometrically estimate the model using both the traditional panel approach (see Stavins and Jaffe 1990, Pfaff 1999) and a more dynamic approach. The output of any such estimation is a 
prediction of the probability that land is in a given use at a given time, yielding, for instance, the result that an increase in returns to coffee of 10 cents per kilo raises by 0.02 the probability that land in a certain lifezone is planted in coffee in a certain year. The dynamic, or duration-data approach we will use has not previously been applied for land use, but is commonly used in labor economics and technological adoption (see Kiefer 1988, Lancaster 1990). One of our team has used this approach previously (see Kerr and Newell 1999), and we discuss further our proposed use of this approach for the analysis of tropical land use in our HIID paper (Boscolo et al. 1999).

Statistical analysis based on observed land-use choices, such as we will carry out, is increasingly common in the economics literature (see Stavins and Jaffe 1990, Pfaff (1995, 1999), Chomitz and Gray 1996, Geoghegan et al. 1997, Kaimowitz and Angelson 1998, and Cropper et al. 1999). This is not the case outside of economics, e.g. in multi-disciplinary integrated assessment (IA) models. The "engineering" models of land use typical of IA share the starting point of economic modeling, i.e. that people make individually rational land-use choices. However, they assume that people behave precisely according to the modeler's view of how choices are made, imposing a very specific structure on land-use decision making (Hall et al. 1995's GeoMod1, Veldkamp and Fresco 1995, and Bouman et al. 1997 consider Costa Rica). The advantage is that detail can be incorporated into the hypothesized model (although the assumptions are stronger as the model gets more detailed). For instance, such models can forecast the use of technologies or crops not currently in use anywhere (and thus whose use simply can not be observed). Also, they can use detailed information on locally variable returns to land uses, or on complex non-linear effects.

However, engineering models must assume that they have perfectly represented reality. Their outputs suffer when their particular specific assumptions about how decisions are made do not capture all aspects of actual decision making. In that case, estimates may not explain current behavior well, let alone predict future responses. Further, such a divergence between model and reality must be expected, as no model could possibly contain all the information available to land users, including concerns about risk, credit constraints, perceived security of tenure, limits on information (e.g., ignorance of some of the possible cropping strategies), bounded ability to calculate the precisely optimal action, lags in response to stimuli, perspective on migration choices and, importantly, knowledge of the possibilities for substituting one activity for another.

Other approaches to land-use analysis have been tried. Demographically-oriented works were mentioned above as tending to focus too narrowly on population. In the extreme, population may be the only explanatory factor considered. Other sorts of analyses may not be predictive at all, and instead focus on interpolating land use between observations. For example, starting with two years' observations on aggregate forest clearing for a given area, such analysis might distribute the clearing spatially within that area over the intervening period (the algorithms used may or may not be economic in nature). However, non-predictive analysis is not useful for our purposes.

Thus, while others have considered land use in Costa Rica, given the opportunities for analysis and the interest in participation in $\mathrm{C}$ trading, there is a real need for organized, observationallyand economically-based analysis of land use. Our approach provides such analysis. First, our use of observations of actual land use and factors in returns permits analysis of actual rather than 
hypothetical behavior. Second, the modeling of economic choices suggests in an organized way what factors need to be observed, as well as how statistical analyses could reveal their effects.

We will apply this approach to both aggregate (district-level) and disaggregate (pixel-level) data on land use and factors that affect land use. While the basic approach will be the same regardless of data aggregation, naturally there are advantages of more disaggregate information. However, within our policy context, there may also be advantages of aggregate data (discussed below).

\subsection{Integrated Analysis}

\subsubsection{Integration and Policy Evaluation}

Our first integrated output is a map from factors that affect land use to the $\mathrm{C}$ sequestration they cause. This map results from chaining our economic analysis, i.e. a map from those factors to the probability that land is in a given use in a given year, to our ecological analysis, i.e. a map from land uses to $C$ storage (in climax vegetation, cleared state, and succession path). The integrated map or function would indicate, e.g., the additional sequestration relative to the baseline caused by the cancellation of a planned road in Costa Rica. It is worth emphasizing that we will be able to apply this chain of disciplinary analyses within a GIS, which will permit spatial simulations.

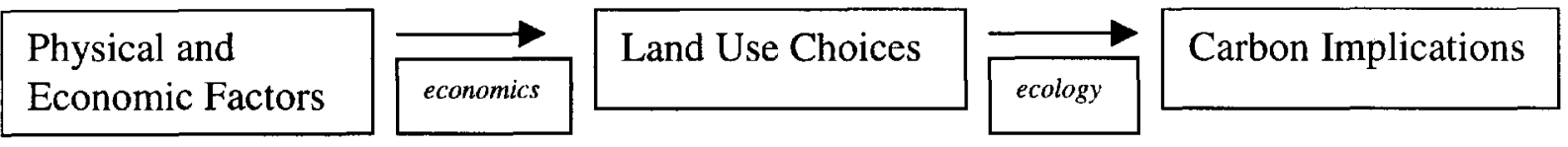

Our results will be comparable with current IA simulation modeling (e.g. Newell and Stavins 1998, the special issue on forestry and climate change of the journal Biomass and Bioenergy in 1995, Richards et al. 1993, Chapter 9 of 1996 IPCC Report, and Moulton and Richards 1990). Other related works which contain consideration of Costa Rica include Vine and Sathaye (1997), Helmer and Brown (1998), and Hall (1998). These do not provide state-of-the-art approaches in both disciplines, as will our efforts to work from the academic to the policy for all aspects of the analysis. As noted, our integrated map could also be plugged into other, existing IA models.

One major policy question is how much sequestration will take place for any given $\mathrm{C}$ reward or, put another way, what $\mathrm{C}$ reward is necessary to achieve any given amount of $\mathrm{C}$ sequestration. $\mathrm{A}$ second major policy question is what value would accrue globally and to individual countries from including $\mathrm{C}$ sequestration within the global mitigation effort. Using our integrated map, the answer to both of these can be seen by working through the effect of an increase in the C reward.

Figure 6 below places in context our estimated map, or C-sequestration supply function. A given reward will induce a certain level of additional protection of forests, with implied sequestration relative to the baseline. A higher reward is expected to induce further forest protection, a greater supply of sequestration, and more $\mathrm{C}$ offsets. When estimated, this sort of $\mathrm{C}$-sequestration supply function answers directly the first policy question (posed either way). The value of sequestration can also be seen in Figure 6. The value to a supplier is its producer surplus, i.e. triangle above the cost of supplying offsets/CERs and below the level of the reward. The global gain from this supply of carbon offsets is the country gain plus the consumer surplus for the CER purchasers. 
Figure 6. Simple illustration of carbon supply and social value

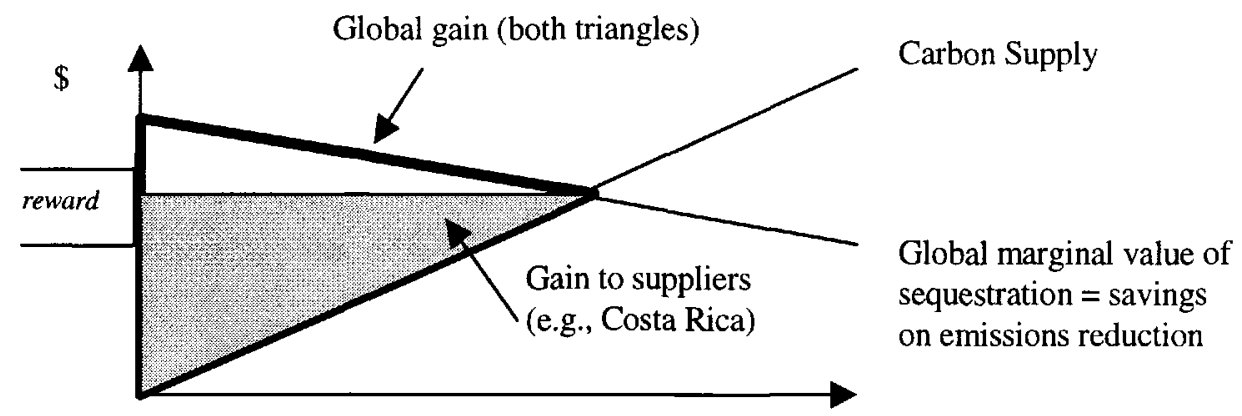

True Carbon Sequestration $=$ CERs created

As noted above, for such a $\mathrm{C}$ trading market to permit tropical $\mathrm{C}$ sequestration efforts to replace emissions-reduction efforts in other countries, there must exist $\mathrm{C}$ baselines. In principle, we might apply our economic analysis for a land-use baseline To do so, we would first project the values of the key factors in land use, and then apply our economic estimates to project land uses. Then we could apply the ecological estimates to calculate implied $\mathrm{C}$ sequestration. In practice, though, this may not be so easy, in large measure because projecting the future values of factors in land use (such as crop, timber or beef prices, or the location of future roads) is not so easy.

However, a ready solution is at hand. Instead of imposing a single projection as the expected future path of land use and carbon (e.g., forest and biomass falls by $0.2 \%$ per year for 50 years), we could propose a function. For example, if beef prices fall, one path would be predicted (e.g., forest cover remaining constant), but if prices stay constant and roads are built, another path would be expected. Such a function is precisely the sort of output that arises from our land-use analysis, e.g. (Forest Cover $)_{t}=\mathrm{f}$ (prices of beef, sugar, banana, coffee; production technology, GDP).

There is a problem, though. Assume, for instance, that our baseline function includes roads. If a road is cancelled because of incentives provided to countries to protect forests, then a country should get credit for reducing roads and thus reducing deforestation. If roads are in the baseline function, however, the country will not. Thus, for baselines to be used to assess the number of credits to give a country for actions taken to protect forests, we might include in our function only factors that are not controlled by countries. For instance, we might use international prices, which arise from a large market, and perhaps also the level of development (e.g., GDP per capita), as it seems unlikely that countries would distort this to get $\mathrm{C}$ payments. We will address this issue of distinguishing exogenous factors (see Kerr et al. 1999 for further such discussion).

\subsubsection{Sensitivity Analysis For Workable Rules}

Our second integrated output will be simplified versions of the very same integrated map or function that relates changes in factors that affect land use to changes in $\mathrm{C}$ sequestration. This will again result from chaining together disciplinary analyses, but in this case those analyses will be the simplified versions of our state-of-the-art models. It is again worth noting that these integrated analyses can be applied within a GIS in order to produce spatially explicit simulations. 
The reason to develop such simplified versions of the disciplinary and integrated analyses concerning tropical forest sinks is that despite the gains from more accuracy, which arise from having the envisioned $\mathrm{C}$ sequestration in fact come about, the increased effort and complexity required impose costs. A first obvious cost of increasing accuracy is an increase in direct costs of the analyses. For example, during the Pilot Phase of Joint Implementation, it was observed that generating $\mathrm{C}$ measures can be a significant cost. Second, both direct costs and uncertainty about the outcome of the certification process will discourage potential projects. This cost of increased complexity, then, is that fewer $\mathrm{C}$ trades will take place, so the gains from trade will be lost. The third cost of more data and more complex computations is an increased scope for manipulation. Complex rules may become black boxes which for many participants are not transparent. Also, as more complex rules involve more costly data collection, this may reduce actual monitoring efforts. Ironically, then, effort and complexity to reduce some errors may in fact increase others.

Given these motivations, we would like to derive simplified but accurate versions of the economic and ecological and ultimately integrated analyses. As mentioned above, for a complex process-based ecological model like CENTURY, meta-modeling regression analysis based on the simulated results of the full CENTURY model could provide a simpler version driven by only a few controlling variables. This would require fewer inputs but, ideally, still provide accuracy. For a simpler, empirically-based ecological model like the LZS, there are also choices of this type. For instance, one might conclude that the first level regressions alone are sufficiently accurate, i.e. that the additional cost of parametrizing the second level is not worthwhile. On the economic side, certainly some key factors such as transport costs and ecological constraints are clear candidates for such simpler models. Another natural focus, when considering the ability to apply such a model in other countries, is the effects of economic development. Note the value of a data-rich country like Costa Rica; to estimate such effects, we need data for periods featuring different paces of development, e.g. before, during and after the 1960s and 1970s in Costa Rica.

That in turn raises the issue of the value of being able to work (as we can) at an aggregate level. While pixel-level data may be available for Costa Rica for earlier periods, for many countries only aggregated data may be available, in particular for earlier periods. Also, more generally, even if it may be possible to get pixel-level data, it may be cheaper and easier to collect aggregate data for other countries. That would be one sort of simpler model. Finally, the statistical analysis will be simpler when using aggregate data, another reason why this would be a simpler model.

In summary, based on the foundation of advances in both economic and ecological analyses, we will apply our basic integrated approach to the pursuit of both our first goal, i.e. a C-sequestration supply function, and our second goal, of contributing to the design of CER rules. This approach involves the use of Costa Rica as an intensive case study with abundant data, which permits our attempts to make the resulting estimates as high-quality and as generalizable as possible. The second goal, building on top of the first, includes the development of simplified versions of our state-of-the-art models, which will retain sufficient explanatory power while being easier and cheaper to use. If this sort of search for CER rules credible and workable enough for policy does not succeed, then society will be unable to reap the potential of tropical forest carbon sinks. 


\section{REFERENCES}

Allen, Julia C. and Douglas F. Barnes (1985). "The Causes of Deforestation in Developing Countries". Annals of the Association of American Geographers 75:163-184.

Bouman, Bas A. M., Hans G. P. Jansen, Rob A. Schipper, Andre Nieuwenhuyse and Huib Hengsdijk (1997). "A methodology for sustainable land use exploration at the regional level: application to the Atlantic Zone of Costa Rica". Draft manuscript. Wageningen Agricultural University, The Netherlands.

Boscolo, Marco, Suzi Kerr, Alex Pfaff, and Arturo Sanchez (1999). "What role for tropical forests in climate change mitigation? The case of Costa Rica" Development Discussion Paper \#675, Harvard Institute of International Development.

Brown S. (1997). Estimating biomass and biomass change of tropical forests: a primer. FAO Forestry Paper. FAO, Rome.

Brown, S., A.J.R. Gillespie, and A.E. Lugo. 1989. Biomass estimation methods for tropical forests with applications to forest inventory data. Forest Science 35: 881-902.

Centro Cientifico Tropical. (1982). Costa Rica: Perfil Ambiental, Estudio de Campo.

Cole, C.V., K. Paustian, E.T. Elliot, A.K. Metherell, D.S. Ojima, W.J. Parton. 1993. Analysis of agroecosystem carbon pools. Water, Air and Soil Pollution 70: 357-371.

Chomitz, Kenneth M. and David A. Gray (1996). "Roads, Land Use and Deforestation: A Spatial Model Applied to Belize". World Bank Economic Review 10(3):487-512.

Cooper, C.F. 1983. Carbon storage in managed forests. Canadian Journal of Forest Research 13:155-166.

Cropper, Maureen and Charles Griffiths (1994). "The Interaction of Population Growth and

Environmental Quality". American Economics Review: Papers and Proceedings 84(2):250-254.

Cropper, Maureen, Charles Griffiths, and Muthukumara Mani (1999). "Roads, Population Pressures, and Deforestation in Thailand, 1976-1989". Land Economics 75(1):58-73.

Crow, T.R. 1978. Common regressions to estimate tree biomass in tropical stands. Forest Science 24:110.

Cummings, D.L., J.B. Kauffman, and R.F. Hughes. Total aboveground biomass, forest volume, and tree density of Amazonian tropical forest delineated by projecto RADAMBRASIL in Northern Rondonia, Brazil. In review in Ecological Applications.

Ewel, J., C. Berish, B. Brown, N. Price and J. Raich, 1981. Slash and burn impacts on a Costa Rican wet forest site. Ecology, 62: 816-829.

Fassbender, H.W., J. Beer, J. Heuveldop, A. Imbach, G. Enriquez and A. Bonnemann, 1991. Ten year balance of organic matter and nutrients in agroforestry systems at CATIE, Costa Rica. For. Ecol. Manag., 45: 173-183. 
Fernandes, D.N. and R.L. Sanford, Jr., 1995. Effects of recent land-use practices on soil nutrients and succession under tropical wet forest in Costa Rica. Conserv. Biol., 9: 915-922.

FONAFIFO (1998). Mapa de Cobertura Forestal de Costa Rica. San Jose, Costa Rica.

Geoghegan, J., L. Wainger and N. Bockstael (1997). "Spatial Landscape Indices in a Hedonic Framework: An Ecological Economics Analysis Using GIS". Ecological Economics 23:251-264.

Gonzalez, J.E. and R.F. Fisher, 1994. Growth of native forest species planted on abandoned pasture land in Costa Rica. For. Ecol. Manag., 70: 159-167.

Gower, S.T., 1987. Relations between mineral nutrient availability and fine root biomass in two Costa Rican tropical wet forests: A hypothesis. Biotropica 19: 171-175.

Haggar, J.P., E.V.J. Tanner, J.W. Beer and D.C.L. Kass, 1993. Nitrogen dynamics of tropical agroforestry and annual cropping systems. Soil Biol. Biochem., 25: 1363-1378.

Haggar, J.P. and J.J. Ewel, 1995. Establishment, resource acquisition, and early productivity as determined by biomass allocation patterns of three tropical tree species. For. Sci., 41: 689-708.

Hall, C.A.S., R.P. Detwiler, P. Bogdonoff, and S. Underhill (1985). "Land-use change and carbon exchange in the tropics 1. Detailed estimates for Costa Rica, Panama, Peru, and Bolivia." Environmental Management 9: 313-333.

Hall, C.A.S., H. Tian, Y. Qi, G. Pontius and J. Cornell (1995). "Modelling spatial and temporal patterns of tropical land-use change". Journal of Biogeography 22:753-757.

Hall, C.A.S., ed. (1998). Ecology of Tropical Development: the myth of sustainable development in Costa Rica. Academic Press, New York.

Harrison, Susan (1991). "Population Growth, Land Use and Deforestation in Costa Rica, 1950-1984." Interciencia 16(2):83-93.

Helmer E.H. and S. Brown (1998). "Gradient analysis of biomass in Costa Rica and a first estimate of country-wide emissions of greenhouse bases from biomass burning", In press in: C.A.S. Hall (Ed.) Ecology of tropical development, the myth of sustainable development in Costa Rica. Academic Press.

Holdridge, L.R., Grenke, W.C.,Hatheway, W.H.,T.Liang, and J.A.Tosi,Jr. (1971). Forest Environments in Tropical Life Zones: A Pilot Study. Pergamon Press, Oxford.

Holdridge, L.R., 1967. Life Zone Ecology. Tropical Science Center, San Jose, Costa Rica

Houghton, R.A., D.L. Skole, and D.S. Lefkowitz. 1991. Changes in the landscape of Latin America between 1850 and 1985 II. Net release of CO2 to the atmosphere. Forest Ecology and Management 38.

Hughes, R.F., J.B. Kauffman, and V.J. Jaramillo. (a.) Deforestation and land use in tropical evergreen forests of the Los Tuxtlas Region, Mexico: Consequences for biomass, carbon, and nutrient pools. In press in Ecological Applications. 
Hughes, R.F., J.B. Kauffman, and V.J. Jaramillo. (b.) Biomass, C, and nutrient dynamics of secondary forests in a humid tropical region of Mexico. In press in Ecology.

Hughes, R.F., D.L. Cummings, and J.B. Kauffman. Fire in the Brazilian Amazon: 3. biomass, carbon, and nutrient pools and losses in slashed secondary forests. Oecologia, in review.

Instituto Meteorologico Nacional (1994). Mapa de Uso de la Tierra de Costa Rica. San Jose, Costa Rica.

Kaimowitz D. and A. Angelsen (1998). Economic Models of Tropical Deforestation: A Review. CIFOR.

Kauffman, J.B., D.L. Cummings, and D.E. Ward (1998a). Fire in the Brazilian Amazon: 2. Biomass, nutrient pools and losses in cattle pastures. Oecologia 113: 415-427.

Kauffman, J.B., D.L. Cummings, and R.F. Hughes (1998b). Biomass decline in Amazon forest fragments. Science 282: 1611

Kauffman, J.B., D.L. Cummings, D.E. Ward, R. Babbitt. 1995. Fire in the Brazilian Amazon: 1. Biomass, nutrient pools, and losses in slashed primary forests. Oecologia 104: 397-408.

Kauffman, J.B., D.L. Cummings, and V.J. Jaramillo. Biomass and structure of tropical deciduous forests and pastures in the Chamela region of Mexico. M.S. in preparation.

Kerr, Suzi, Alexander S.P. Pfaff, Arturo Sanchez, David Schimel, Joseph Tosi, and Vicente Watson (1999). "Making Tropical Carbon Sinks Feasible Within The CDM: acknowledging the costs of accuracy \& a suggested approach". Mimeo, Columbia University.

Kerr, Suzi and Richard Newell (1999). “Technology Adoption In Response To Environmental Regulation: evidence from the US lead phasedown" Paper at AERE/ASSA Annual Meetings, January 5, NY, NY.

Kiefer, Nicholas M. (1988) "Economic Duration Data and Hazard Functions" Journal of Economic Literature Vol. XXVI, June, 646-679

Lancaster, Tony (1990) The Econometric Analysis of Transition Data Econometric Society Monograph No. 17, (Cambridge University Press)

Lieberman, D. and M. Lieberman, 1987. Forest tree growth and dynamics at La Selva, Costa Rica (19691982). J. Trop. Ecol., 3: 347-358.

Liu, S., W.A. Reiners, M. Keller and D. S. Schimel, 1999a. Simulation of nitrous oxide and nitric oxide emissions from tropical moist primary forests in the Costa Rican Atlantic Zone. Environmental Modeling and Software (in review).

Liu, S., W.A. Reiners, M. Keller and D.S. Schimel, 1999b. Model simulation of changes in N2O and NO emissions with conversion of tropical rain forests to pastures in the Costa Rican Atlantic Zone. Global Biogeochem. Cycles (in press).

Liu, S., W.A. Reiners, B.A.M. Bouman, K. Gerow, D.S. Schimel and M. Keller, 1999c. Simulated impacts of edaphic, biological and management factors on $\mathrm{N} 2 \mathrm{O}$ and $\mathrm{NO}$ emissions from pastures in the Atlantic Zone, Costa Rica. (in preparation). 
Liu, S. and W.A. Reiners, 1999. Interfacing a N2O flux model with GIS-based spatial batabase for scaling-up N2O fluxes from sites to a humid tropical region. Computer \& GeoSciences (in review).

Lugo, Ariel E., R. Schmidt, S. Brown (1981). "Tropical Forests in the Caribbean". Ambio 10:318-24.

Lutz, Ernst and Herman Daly (1990). "Incentives, Regulations and Sustainable Land Use in Costa Rica". Environment Working Paper No. 34, The World Bank, Washington, DC.

Marrs, R.H., J. Proctor, A. Heaney and M.D. Mountford, 1988. Changes in soil nitrogen-mineralization and nitrification along an altitudinal transect in tropical rain forest in Costa Rica. J. Ecol., 76: 466-482.

Martini, J.A. and M. Macias, 1974. A study of six Latosols from Costa Rica to elucidate the problems of classification, productivity and management of tropical soils. Soil Sci. Soc. Am. Proc., 38: 644-652.

Matson, P.A., P.M. Vitousek, J.J. Ewel, M.J. Mazzarino and G.P. Rebertson, 1987. Nitrogen transformations following tropical forest felling and burning on a volcanic soil. Ecology, 68: 491-502.

Mazarino, M.J., L. Szott and M. Jimenez, 1993. Dynamics of soil total C and N, microbial biomass, and water-solubale $\mathrm{C}$ in tropical agroecosystems. Soil Biol. Biochem., 25: 205-214.

Montagnini, F., K. Ramstad and F. Sancho, 1993. Litterfall, litter decomposition and the use of mulch of four indigenous tree species in the Atlantic lowlands of Costa Rica. Agroforestry Systems, 23: 39-61.

Montagnini, F. and F. Sancho, 1990. Impacts of native trees on tropical soils: A study in the Atlantic lowlands of Costa Rica. Ambio, 19: 386-390.

Motavalli, P.P., C.A. Palm, W.J. Parton, E.T. Elliot and S.D. Frey, 1994. Comparison of laboratory and modeling simulation methods for estimating carbon pools in tropical forest soils. Soil Biol. Biochem., 26.

Motavalli, P.P., C.A. Palm, W.J. Parton, E.T. Elliot and S.D. Frey, 1995. Soil pH and organic C dynamics in tropical forest soils: Evidence from laboratory and simulation studies. Soil Bio. Biochem., 27.

Moulton, Robert J. and Kenneth R. Richards (1990). "Costs of Sequestering Carbon Through Tree Planting and Forest Management in the United States". GTR WO-58. Dept. of Agriculture, Forest Service.

Parton, W.J., D.S. Schimel, C.V. Cole and D.S. Ojima, 1987. Analysis of factors controlling soil organic matter levels in Great Plains grasslands. Soil Sci. Soc. Am. J., 51: 1173-1179.

Parton, W.J., J.M.O. Scurlock, D.S. Ojima, T.G. Gilmanov, R.J. Scholes, D.S. Schimel, T. Kirchner, J.C. Menaut, T. Seastedt, E.G. Moya, A. Kamnalrut and J.I. Kinyamario, 1993. Observations and modeling of biomass and soil organic matter dynamics for the grassland biome worldwide. Global Biogeochem. Cycles 7: 785-809.

Pfaff, Alexander S.P. (1995). "The Economics of Deforestation: Evidence from the Brazilian Amazon and New England". Ph.D. Dissertation, M.I.T., Department of Economics. 
Pfaff, Alexander S.P. (1999). "What Drives Deforestation in the Brazilian Amazon? Evidence from Satellite and Socioeconomic Data". Journal of Environmental Economics and Management 37(1):26-43.

Post, W.M., et al., 1982. Soil carbon pools and world life zones. Nature 298:156-159.

Putz, F.E. 1983. Liana biomass and leaf area of a "tierra firme" forest in the Rio Negro Basin, Venezuela. Biotropica 15: 185-189.

Reeves, M., R. Lal, T. Logan and J. Sigaran, 1997. Soil nitrogen and carbon response to maize cropping system, nitrogen source, and tillage. Soil Sci. Soc. Am. J., 61: 1387-1392.

Reiners, W.A., A.F. Bouwman, W.F. Parsons and M. Keller, 1994. Tropical rain forest conversion to pasture: Changes in vegetation and soil properties. Ecol. Appl., 4: 363-377.

Reiners, W.A., S. Liu, K. Gerow, M. Keller, and D.S. Schimel, 1999. Land use changes in Costa Rica's Atlantic Zone: Net effects on $\mathrm{N} 2 \mathrm{O}$ and $\mathrm{NO}$ emissions. (in preparation).

Richards K.R., R.J. Moulton and R.A. Birdsey (1993). "Costs of Creating Carbon Sinks in the U.S." Energy Conversion Management 34(9-11):905-912.

Rodriguez, J., L. Corrales, L. Pratt (1998). Potencial de Carbono y Fijacion de Dioxido de Carbono de la Biomasa en pie por encima del suelo en los bosques de la Republica de Belice, Costa Rica, El Salvador, Guatemala, Nicaragua, Panama, Honduras. Documentos de Trabajo.

Rosero-Bixby L. and A. Palloni (1996). Population and Deforestation in Costa Rica. Paper presented at the Annual Meeting of the Population Association of America in New Orleans.

Rudel, Thomas K. (1989). "Population, Development, and Tropical Deforestation: A Cross-National Study." Rural Sociology 54(3), pp.327-338.

Sader, S., \& Joyce, A. (1988, March 1988). Deforestation Rates and Trends in Costa Rica, 1940 to 1983. BIOTROPICA, 20, 11-19.

Sanchez-Azofeifa, G.A. and Quesada-Mateo, C. (1995) Deforestation, carbon dynamics and sustainable mitigation measures in Costa Rica: the Puerto Viejo de Sarapiqui case study. Interciencia 20:396.

Sanchez-Azofeifa, G. A. (1996). Assessing Land Use / Cover Change in Costa Rica. Earth Sciences Department. Durham, New Hampshire, University of New Hampshire.

Sanchez-Azofeifa, G.A.; Skole, L.D.; Harriss, R.C.; and Quesada-Mateo, C.A. (1997) Tropical deforestation and habitat fragmentation in Costa Rica (1986-1991). AMBIO (accepted).

Sanchez-Azofeifa, G. A. and C. A. Quesada-Mateo (1998). "Monitoring deciduous forest in Costa Rica: New insights from remote sensing." International J. of Remote Sensing (in review).

Sanchez-Azofeifa, G.A.; Quesada-Mateo, C.; Gonzales-Quesada, P.; Dayanandan, S.; Bawa, K.S. (1999a) Protected areas and conservation of biodiversity in the tropics. Conservation Biology. 13 (2).

Sanchez-Azofeifa, G.A.; Daily, G.; Ehrlich, P.; Wein, R. (1999b). Effectiveness of National Parks and Biologic Reserves to control tropical deforestation. Conservation Biology. Submitted. 
Schimel, D.S., B.H. Braswell, E.A. Holland, R. Mckeown, D.S. Ojima, T.H. Painter, W.J. Parton and A.R. Townsend, 1994. Climatic, edaphic, and biotic controls over storage and turnover of carbon on soils. Global Biogeochem. Cycles, 8: 279-293.

Schimel, D.S., B.H. Braswell and W.J. Parton, 1997. Equillibrium of the terrestrial water, nitrogen, and carbon cycles. Proc. Natl. Acad. Sci. USA, 94: 8280-8283.

Smith, P. et al., 1997. A comparison of the performance of nine soil organic matter models using datasets from seven long-term experiments. Geoderma, 81: 153-225.

Stavins, Robert N. and Adam Jaffe (1990). "Unintended Impacts of Public Investments on Private Decisions: The Depletion of Forested Wetlands". American Economic Review, 80(3):337-352.

Newell, Richard G. and Robert N. Stavins (1998). "Climate Change and Forest Sinks: Factors Affecting the Costs of Carbon Sequestration”. Faculty Research Working Paper Series, R98-14, Harvard/KSG.

Stuhrmann, M., C. Bergmann and W. Zech, 1994. Mineral nutrition, soil factors and growth rates of Gmelina arborea plantations in the humid lowlands of northern Costa Rica. For. Ecol. Manag., 70: 135.

Tosi, J.A., Jr. (1997). An ecological model for the prediction of carbon offsets by terrestrial biota. Centro Cientifico Tropical, San Jose, Costa Rica.

Uhl, C., R. Buschbacher, and E.A.S. Serrao. 1988. Abandoned pastures in eastern Amazonia. I. Patterns of plant succession. Journal of Ecology 76: 663-681.

Van Wagner, C.E. 1968. The line intersect method in forest fuel sampling. Forest Science 14:20.

Veldkamp, A. and L. O. Fresco (1995) Modelling land use changes and their temporal and spatial variability with CLUEA; A pilot study for Costa Rica Wageningen Agricultural University, Department of Agronomy, Report No. 410100086

Veldkamp, E., 1994. Organic carbon turnover in three tropical soils under pasture after deforestation. Soil Sci. Soc. Am. J., 58: 175-180.

Veldkamp, E., A.M. Weitz, I.G. Starritsky and E.J. Huising, 1992. Deforestation trends in the Atlantic Zone of Costa Rica: A case study. Land Degrad. \& Rehabilit., 3: 232-244.

VEMAP members, 1995. Vegetation/ecosystem modeling and analysis project. Comparing biogeography and biogeochemical models in a continental-scale study of terrestrial ecosystem responses to climate change and $\mathrm{CO} 2$ doubling. Global Biogeochem. Cycles, 9: 407-437.

Vine, Edward and Jayant Sathaye (1997). The Monitoring, Evaluation, Reporting and Verification of Climate Change Mitigation Projects: Discussion of Issues and Methodologies and Review of Existing Protocols and Guidelines. Lawrence Berkeley National Laboratory Report No. 40316. Berkeley, CA.

Watson R.T. et al. (1996). Climate Change 1995. Impacts, Adaptations and Mitigation of Climate Change: Scientific-Technical Analyses. Cambridge University Press. 


\title{
1998-1999 Discussion Paper Series
}

\author{
Department of Economics \\ Columbia University \\ 1022 International Affairs Bldg. \\ 420 West 118 th Street \\ New York, N.Y., 10027
}

The following papers are published in the 1998-99 Columbia University Discussion Paper series which runs from early November to October 31 of the following year (Academic Year).

The following is the Columbia University, Economics Department's website where viewers may access more information about the Discussion Paper series.

Http://www.columbia.edu/cu/economics/

All 1997-98, 1998-99 and future papers will be acessible on-line at the following website:

\section{Http://www.ssrn.com}

Discussions papers that are not available on-line maybe obtained by written request to the Economics Department. Please check the Ordering Papers section for details.

\section{Copy Requests}

To order 1996-97 and prior discussion papers, please write to the Discussion Paper Coordinator at the address below, along with a check for the appropriate amount, made payable to:

Department of Economics, Columbia University. Please be sure to indicate the discussion paper number or the particular series in your written request. Orders cannot be processed without payment, and they cannot be taken over the phone, or by fax or email.

Past discussion papers (1996-97 and prior papers) are available for purchase in U.S. dollars only, at the cost of:

US: per paper $\$ 4.00 /$ per series: $\$ 140.00$

Canada: per paper $\$ 5.00 /$ per series: $\$ 150.00$

Overseas: per paper $\$ 7.00 /$ per series $\$ 185.00$ 
1998-99 Discussion Papers

Economics Department, Columbia University

\begin{tabular}{|c|c|c|}
\hline $9899-01$ & Propensity Score Matching Methods for Non-experimental Causal Studies & Deheija $\mathrm{R}$ \\
\hline $9899-02$ & Institutional Solutions to the Principal-Agent Problem in African Health Care & $\begin{array}{l}\text { Leonard, } \mathrm{K} \text {. } \\
\text { Leonard, D. }\end{array}$ \\
\hline $9899-03$ & The Economics of Repeated Extortion & $\begin{array}{l}\text { Choi, J.P. } \\
\text { Thum, M. }\end{array}$ \\
\hline $9899-04$ & To Pay or Not to Pay: Managerial Decision making and Wage Withholding in Russia & $\begin{array}{l}\text { Desai, } \mathrm{P} \\
\text { Idson, } \mathrm{T} \text {. }\end{array}$ \\
\hline $9899-05$ & Wage Arrears, Poverty, and Family Survival Strategies in Russia & $\begin{array}{l}\text { Desai, } \mathrm{P} \text {. } \\
\text { Idson, T. }\end{array}$ \\
\hline $9899-06$ & $\begin{array}{l}\text { Averaged Periodogram Spectral Estimation with Long Memory Conditional } \\
\text { Heteroscedasticity }\end{array}$ & Henry, $M$. \\
\hline $9899-07$ & $\begin{array}{l}\text { Household Production, the Bundling of Services and Degradation, and Non- } \\
\text { monotonic Environmental Engel Curves }\end{array}$ & $\begin{array}{l}\text { Chaudhuri, S. } \\
\text { Pfaff, A. }\end{array}$ \\
\hline $9899-08$ & $\begin{array}{l}\text { A Carbon Sequestration Supply Function And Development of Feasible Clean } \\
\text { Development Mechanism Rules for Tropical Forest Carbon Sinks }\end{array}$ & $\begin{array}{l}\text { Kerr, S. } \\
\text { Pfaff, A. }\end{array}$ \\
\hline
\end{tabular}

